\title{
Federal Banks and Federal Jurisdiction in the Progressive Era: A Case Study of Smith v. K.C. Title \& Trust Co.
}

\author{
Larry Yackle*
}

\section{INTRODUCTION}

This article probes the anatomy and context of the Supreme Court's decision in Smith v. K.C. Title \& Trust Co. ${ }^{1}$ Charles E. Smith, a stockholder in the Trust Company, filed a bill in equity in the United States District Court for the Western District of Missouri. He sought an injunction preventing the company, its directors, and managers from using corporate funds to purchase tax-exempt bonds issued by Federal Land Banks or Joint Stock Land Banks, established under the Farm Loan Act of 1916 and supervised by the Farm Loan Board. His theory was that the Trust Company's charter permitted investments only in lawful securities - a criterion these bonds failed to meet because the 1916 Act in general and tax exemptions for the bonds in particular were unjustified under any of Congress's enumerated powers. The district court rejected Smith's contentions on the merits and dismissed the bill. The Supreme Court affirmed in an opinion by Justice Day, upholding the Act in all

\footnotetext{
* Professor of Law and Basil Yanakakis Faculty Research Scholar, Boston University School of Law.

Many colleagues and student assistants helped bring this study together, including Joshua Bearce, Frank Brooker, Meredith Ciufo, Kristin Collins, Michael G. Collins, Nicholas Costa, Mark Davis, Jamie Frank, Morton Horwitz, William Kaleva, Pnina Lahav, Evan Tsen Lee, Gerald Leonard, Justin Levinson, Nancy Moore, Lumen Mulligan, Jacqueline Nyenke, Kevin Outterson, Randy Roth, Zoe Sajor, David Seipp, Avi Soifer, David Walker, and Jeanette Yackle. I also had the benefit of faculty workshops at Boston University School of Law and the William S. Richardson School of Law, University of Hawaii.

I received special research assistance at these libraries and institutions: The Filson Library, Louisville, Kentucky (Shirley Harmon), the Harvard Law School Library, Historical and Special Collections, Cambridge, Massachusetts (Edwin Moloy), the Mortgage Bankers Association, Washington, D.C. (Amber Lawrence and Phyllis Slesinger), the National Archives and Records Administration, Kansas City, Missouri (Stephen Spence); the Spencer Library, Lawrence, Kansas (Ann Elliott Parkins), the William S. Richardson School of Law Library, Honolulu, Hawaii (Roberta Woods), and the Pappas Law Library of Boston University (Jennifer Eckblaw, Terri Geiger, and especially Stefanie Weigmann).
}

1. 255 U.S. 180 (1921). 
particulars. Justice Holmes dissented on the ground that the district court had acted without jurisdiction. Justice McReynolds joined Holmes's dissent. Justice Brandeis did not participate.

$$
* * *
$$

The Smith case is an old chestnut in the law of federal courts, usually cited for its treatment of the district court's original subject matter jurisdiction. None of the parties raised the jurisdiction issue; Justice Day addressed it sua sponte. Day explained that the district court had acted properly under $\S 24$ of the Revised Judicial Code, the precursor of the modern federal-question jurisdictional provision, 28 U.S.C. $\S 1331$. Inasmuch as the case implicated the validity of a federal statute, he said, it arose "under the Constitution." 2 The Supreme Court itself then had immediate appellate jurisdiction under $\S 238$ of the Judicial Code, which permitted the circuit court of appeals to be bypassed when the constitutionality of a "law of the United States" was drawn into question. $^{3}$ In dissent, Justice Holmes invoked his own opinion for the Court in a previous (and equally famous) case, American Well Works. ${ }^{4}$ In Well Works, Holmes had explained that a suit "arises under the law that creates the cause of action." In Smith, he insisted, the "cause of action" was created by state law, and it followed that original federal jurisdiction was not established under $\S 24{ }^{6}$

For generations, the Court's jurisdictional holding in Smith was acknowledged as authoritative, yet honored primarily in the breachunderstandable perhaps in its own peculiar circumstances, but out of step with the general doctrine announced in Well Works and with the broader stream of precedents in point. ${ }^{7}$ Then, in the Grable case a few years ago, ${ }^{8}$ the Supreme Court reaffirmed the result in Smith and offered a

2. In relevant part, $\S 24$ read this way: "The district courts shall have original jurisdiction ... [of] all suits of a civil nature, at common law or in equity, ... where the matter in controversy exceeds ... three thousand dollars, and ... arises under the Constitution or laws of the United States, or treaties made, or which shall be made, under their authority." Revised Judicial Code, ch. 231, 36 Stat. 1091 (1911) (codified as amended at 28 U.S.C. $\S 1331$ ). Currently, § 1331 provides that district courts have original jurisdiction in "all civil actions arising under the Constitution, laws, or treaties of the United States." 28 U.S.C. § 1331 (2012).

3. Revised Judicial Code, ch. 231, 36 Stat. 1157 (1911).

4. American Well Works Co. v. Layne \& Bowler Co., 241 U.S. 257 (1916).

5. Id. at 260 .

6. Smith, 255 U.S. at 213-14 (Holmes, J., dissenting).

7. See, e.g., T.B. Harms Co. v. Eliscu, 339 F.2d 823, 827 (2d Cir. 1963).

8. Grable \& Sons Metal Prods. v. Darue Eng'g \& Mfg., 545 U.S. 308 (2005). 
rationale for bringing this old case into the fold. Briefly stated, the modern Court embraces what it takes to be Holmes's general analysis of subject matter jurisdiction in federal-question cases, but recognizes exceptions that capture Smith. ${ }^{9}$

To specialists, a thorough exploration of Smith is intrinsically worthwhile. We need to know what we can about a decision that continues to figure in modern discussions of federal-question jurisdiction. To everybody else, an investigation of Smith sounds like a snooze. It is not. There is a wider, deeper story here worth the tellinga story about another time when national economic policy could be made and implemented in a way that appears strange (and sadly alien) today. Members of Congress from both political parties could cooperate in the creation of public institutions to serve the social welfare at the expense of private corporations. Affected companies could ask the federal courts to protect their businesses in the name of the Constitution. The courts could fashion a procedural framework for entertaining the constitutional challenge. And the Supreme Court could easily validate the economic policy forged via democratic processes.

There is some human interest in the Smith story. For students of the Court, Holmes's involvement is enough in itself. But other colorful characters participated. The shareholder, Smith, was represented by William Marshall Bullitt, formerly Solicitor General in the Taft Administration and one of the premier corporate litigators of his generation. Bullitt was an extravagant personality whose avocation was the collection of rare books on mathematics and astronomy. ${ }^{10}$ It was said he could "say more words in a minute than any man in Kentucky." 11

The Farm Loan Act was defended by no less a figure than Charles Evans Hughes, just off his unsuccessful run for the presidency. Hughes represented Federal Land Banks, which joined the suit as intervenors. The other two principal attorneys on the defense side were George Woodward Wickersham (the former Attorney General and a close friend of Bullitt's from their days at the Justice Department) ${ }^{12}$ and William Gibbs McAdoo (the former Secretary of the Treasury under Wilson who married the boss's daughter). ${ }^{13}$ Wickersham and McAdoo argued for

9. Id. at 308 .

10. Mark Davis, Solicitor General BullitT 169-77 (2011).

11. William Bullitt, Ex-U.S. Aide, Dead, N.Y. TiMES, Oct. 4, 1957, at 23.

12. DAVIS, supra note 10, at 71 (reporting that Wickersham's office was next to Bullitt's and describing their close working and personal relationship).

13. McAdoo's wife was Woodrow Wilson's daughter, Eleanor. JOHN J. BroESAMLE, 
independent intervenors, Federal Joint Stock Land Banks. McAdoo also appeared for the United States as amicus curiae, signing the government's brief in the capacity of Special Assistant to the Attorney General.

The battle of these giants of the American bar was all the more exciting inasmuch as they joined issue on the merits of the constitutional questions and refused to be distracted by procedural obstacles. Everyone involved wanted a definitive ruling that either cut Federal Land Banks and Joint Stock Banks out of the picture or removed the constitutional cloud that surrounded them. This was a classic test case. The real interests backing the Smith suit were private mortgage lenders anxious that federally chartered banks would drive them out of business. The real defendants were the intervenor federal banks whose validity was under attack. Those federal banks were meant to displace private mortgage banks, but had been unable to do so because their legal status, in particular their ability to sell tax-exempt bonds, was under suspicion. Various attempts to reassure investors had been unsuccessful, and an authoritative decision upholding the Act had become a palpable necessity. Millions were at stake (real money at the time), not to mention the stability of far-ranging economic arrangements tied to agriculture.

The litigation in Smith provides a snapshot of another time in American history when the country was somehow more governable than it is now. Generalization is dangerous, of course. There were lots of contradictory political themes in the Progressive Era. But among them was a discernible impulse to establish governmental instruments for advancing the public good. There was an accompanying jurisprudence, which effectively allowed corporations to challenge federal social welfare legislation that reduced their profits. Then again, once corporations gained a foothold in federal court, they could be unsuccessful on the merits when the judiciary sustained Congress's decision to erect public substitutes for private business.

No one thinks the Supreme Court was bent on a socialist agenda in the early years of the twentieth century - as though, if Congress had only chosen to displace private enterprise with public institutions, the Court would have been perfectly content and, into the bargain, would never have entertained the federal regulatory measures Congress in fact enacted and the Court in fact considered and struck down as the New 
Deal took shape. There is no viable thesis that the Court was troubled only by impositions on private businesses, not their demise. Yet in this instance at least, the Farm Loan Act of 1916 did introduce public entities Congress believed would better serve the common good, and the Supreme Court endorsed a means by which private corporations could launch a constitutional attack only to reject the challenge on the merits.

Part II of this article first describes the conditions that gave rise to the federal government's decision to establish federally chartered banks to foster rural credit and the politics surrounding the 1916 Act, then sketches the content of the Act and the interests it affected, and finally reviews the experience with federally chartered banks and the perceived threat to the private lenders roused to litigation. The Act was a meaningful, bipartisan response to genuine concerns that the agriculture sector needed public support to realize its potential for the benefit of both farmers and others who would flourish along with them. The opposition came from private financial institutions whose businesses would suffer. The political process recognized the competing interests and forged a compromise. Private banks remained dissatisfied and took their case to the courts.

Part III explores the development of the test case, the choice of a shareholder suit as the vehicle, the selection of the nominal plaintiff and defendant, the legal arguments on both sides, and the litigation itself from the initial pleadings to the Supreme Court's decision. The suit in Smith was framed as a shareholder action to defuse three threshold questions: standing to appear in an Article III court, the district court's jurisdiction in equity, and the court's subject matter jurisdiction to entertain an attack on the 1916 Act. The case was plainly friendly, though fiercely argued on the merits. The Court set aside Hughes's contention that Congress could establish the new federal banks under its power to tax and spend for the general welfare and, instead, held that Congress could create the banks as a means of administering the government's own finances - relying on dormant provisions inserted in the Act for the acknowledged purpose of insulating the banks from constitutional attack.

Part IV takes up the question that divided Justice Day and Justice Holmes: the district court's original subject matter jurisdiction. The modern Court thinks Day held that jurisdiction was established under $\S$ 24 because the substantive claim the shareholder advanced against the Trust Company was federal. The Court thinks Holmes used the phrase "cause of action" as that phrase is typically employed today-namely, to describe a litigant's entitlement to seek a judicial remedy on a claim 
rather than the claim itself. Accordingly, the Court thinks Holmes objected to jurisdiction in Smith because, however the shareholder's claim was characterized, his ability to sue came from state rather than federal law. Recent scholarship demonstrates that, at the time, it was commonplace to find federal-question jurisdiction even though a plaintiff's authority to pursue judicial relief rested on nonfederal grounds and that Holmes rejected any distinction between claims and the ability to enforce claims in court. These insights do not necessarily threaten, but in some minds actually support, the modern Court's understanding of what Day and Holmes meant.

There is, however, an alternative reading of the opinions in Smith that better accounts for all we know about the case and its surrounds. According to this alternative interpretation, both Day and Holmes used the phrase "cause of action" to refer to the shareholder's substantive claim, and both agreed that jurisdiction turned on the nature of the claim without regard to any separable entitlement to seek a judicial remedy. They disagreed about whether the claim the shareholder raised (a state claim borrowing its content from the Constitution) was truly federal for jurisdictional purposes. This alternative interpretation does challenge the modern Court's understanding of Smith. Yet it does not suggest that the Court's focus on a litigant's authority to sue as the keystone to federalquestion jurisdiction today is erroneous or unwise, only unsupported by anything Justice Holmes thought and wrote nearly a century ago.

\section{The LeGISLATIVE FACTS}

\section{A. The Path to Legislation}

American agriculture underwent fundamental transformation during the Progressive Era. Farming had historically been a local affair, conducted on a small scale according to traditional techniques. Land was plentiful and cheap, so there was little incentive to make farming efficient. Yet when the supply of land diminished early in the twentieth century, agriculture became more like any other business. Farmers employed more sophisticated methods to improve their yields, adopted commercial practices that previously had been largely confined to manufacturing, and raised their sights to wider markets. ${ }^{14}$ 
In some respects, the evolution of farming was of a piece with so many other populist developments in the period-developments conventionally associated with greater power and improved conditions for common people. ${ }^{15}$ Yet the full story resists any single, tidy narrative. Historians do not agree on the best description of the changes in agriculture, far less on the principal contributing causes, less still on the consequences for farmers and the nation as a whole. There is evidence that farming assumed new forms not (so much or, certainly, entirely) in response to popular social movements, but through the calculated, though disjointed, efforts of urban business interests to exploit agriculture. Railroads, for example, promoted larger, more mechanized, and better funded farming operations to generate shipments of produce to hungry city dwellers. ${ }^{16}$

Innovations in agriculture were accompanied by new financial arrangements. Farming had previously been carried on without significant debt. In this period, farmers began to mortgage their land to private banks and life insurance companies in order to generate funds for equipment and expansion. Many mortgage lenders in rural areas concentrated their activities in this direction, developing a new, specialized, and extremely lucrative farm loan industry. ${ }^{17}$ Questions were raised about the capacity of private mortgage lending to support agriculture's evolving needs. It was commonly said that private banks and insurance companies loaned farmers too little, demanded repayment from farmers too soon, and, most important, charged farmers too much. ${ }^{18}$

15. See Richard Hofstadter, The Age of Reform: From Bryan to F.D.R. 118 (1955) (listing developments in farming during the Populist Era).

16. Michael P. Malone, James J. Hill: Empire Builder of the Northwest 89, 160, 19 199, 254-62 (1996); Roy V. SCOTt, RaIlroad DeVelopment PRograms IN the Twentieth CENTURY 36-55 (1st ed. 1985). See also W.W. Finley, The Railway and the Farmer, THE PROGRESSIVE FARMER, Feb. 17, 1912, at 5 (describing the symbiotic relation between the railroads and agriculture).

17. Robert Lynn Cox, Life Insurance Investments with Special Reference to Farm Mortgages, THE STANDARD, Dec. 11, 1915, at 620 (reporting that banks held large numbers of farm mortgages by 1914 and that life insurance companies held even more).

18. See Robert J. Buckley, Report of the JoInt Committee on RuRal CREDits, H.R. Doc. No. 64-494, at 6 [hereinafter REPORT ON RURAL CREDITS] (1st Sess. 1916) (asserting that farmers were charged "extortionate and inexcusable rates of interest" regardless of usury statutes and "a decent regard for human necessities"). See also 53 CONG. REC., at 1293-94 (1916) (statement of Rep. John Tillman). For other accounts of the circumstances prompting the enactment of the Farm Loan Act, see Robert J. Buckley, The Federal Farm-Loan Act, 25 J. PoL. ECON. 129, 130-31 (1917) [hereinafter Buckley, Farm-Loan Act]; Myron T. Herrick, The Farmer and Finance, ThE ATLANTIC Monthly, Feb. 1913, at 170; and Arne C. WiPrud, The Federal Farm LoAn System in OPERATION 49-50, 76 (1921). 
Political sentiment coalesced around federal legislation that would free farmers from greedy lenders and ensure adequate financing for businesslike farming operations from which so many hoped to prosper. ${ }^{19}$

In 1914, private banks formed the Farm Mortgage Bankers Association (FMBA) to respond to what they regarded as false accusations. Yet by then the question was no longer whether Congress would act, but how, and the FMBA focused primary attention on a lobbying campaign to influence inevitable legislation. In its original statement of principles, the FMBA disclaimed opposition to federal intervention per se and, indeed, formally endorsed the creation of federally chartered land banks - but only so long as new federal banks were not authorized to use public funds to make or guarantee lowinterest loans to farmers. ${ }^{20}$

The campaign for a federal program also defies generalization. Institutions and organizations frequently shifted their stated goals, constantly jockeying for influence. Most of the time, farm organizations like the National Grange and the National Farmers Union promoted direct government loans at low rates. ${ }^{21}$ Most agricultural publications resisted low-interest federal lending, but endorsed other forms of federal legislative action. ${ }^{22}$ Business interests typically preferred the creation of privately funded cooperative lending institutions then popular in Europe - as did Theodore Roosevelt's Country Life Commission. ${ }^{23}$

Congress sent a commission to the continent, ostensibly to study the systems in place there and to identify ideas that might be copied. ${ }^{24}$ The commission reported that rural "peoples banks" and credit associations prevalent in Germany, Austria, and Italy had successfully tailored

19. REPORT ON RURAL CREDITS, supra note 18, at 6 (explaining that farming was now a business demanding large amounts of capital that could be obtained only by borrowing from investors encouraged by new legislation); Buckley, Farm-Loan Act, supra note 18, at 131-32 (explaining that rural credit was a national issue calling for uniform national policy).

20. Proceedings of the Fourth AnNual Convention OF THE Farm Mortgage BanKers AsSOCIATION OF AMERICA 11, 14-19 (1917) [hereinafter 1917 FMBA PROCEEDINGS] (statement of Kingman N. Robins).

21. Stuart W. Shulman, The Origin of the Federal Farm Loan Act: Agenda-Setting in the Progressive Era Print Press 244 (June 1999) (unpublished Ph.D. dissertation, University of Oregon) (on file with Knight Library, University of Oregon).

22. Id. at 239-44.

23. Report of THE COUNTRY Life COMMission, S. Doc. No. 60-705, at 4-5 (1st Sess. 1909); Stuart W. Shulman, The Origin of the Federal Farm Loan Act, in FigHTING FOR THE FARM: RURAL AMERICA TRANSFORMED 113, 116-17 (Jane Adams ed. 2003).

24. See Robert B. Tootell, The Federal Land Banks, in Great AM. CoOperators: Biographical SKetches of 101 Major PioneERs in CoOperative DeVelopment 549, 551-52 (Joseph G. Knapp et al. eds., 1967) (describing this and other European studies). 
financial programs for agriculture that could be adopted in the United States if only small American banks were encouraged to pool their efforts in organizations that would operate under charter from the federal government. ${ }^{25}$ In the Smith case to come (launched just as the United States entered World War I), Bullitt seized upon the commission report as evidence that the 1916 Act amounted to a transplantation of the "German plan" and was "inimical to the spirit of our institutions."26

The Wilson Administration initially resisted anything tasting of subsidies for farmers and hoped to stimulate agriculture by other means. Wilson himself favored educational demonstration and extension programs like those he had established in New Jersey. ${ }^{27}$ The Secretary of Agriculture, David Houston, advised the President that the use of government funds to aid farmers would amount to illegitimate class legislation. ${ }^{28}$ Wilson, in turn, told Congress that farmers should be given no "privilege, such as extending to them the credit of the government itself," 29 and went so far as to threaten a veto if Congress passed a loan program for farmers in $1914 .^{30}$

There was an argument that the general revisions in banking already achieved were sufficient to deal with any difficulties in rural credit. ${ }^{31}$ National banks had previously been barred from making real estate loans, but the Federal Reserve Act had eliminated that prohibition. ${ }^{32}$ Proponents of a special program for agriculture were unpersuaded. National banks could make farm mortgage loans only for five years, nowhere near what many thought farmers needed. ${ }^{33}$ Moreover, it was widely understood that national banks were disinclined to enter the farm

\footnotetext{
25. RePORT OF THE U.S. COMMISSION, S. Doc. No. 63-380, at 9, 11, 31 (2d. Sess. 1914).

26. Appellant's Revised Brief at 7, Smith v. K.C. Title \& Trust Co., 255 U.S. 180 (1921) (No. 199) (brief on reargument). Bullitt acknowledged that the arrangements in the 1916 Act were not necessarily unlawful "merely because the system [was] German." Id. at 8 . But the connection had been made.

27. Carl R. Woodward, Woodrow Wilson's Agricultural Philosophy, 14 AGRIC. HIST. 129, 130 (1940).

28. 1 David F. Houston, Eight YeARs With Wilson's CABINET 84 (1926).

29. Myron T. Herrick, The Federal Farm Loan Act, The Atlantic Monthly, Feb. 1917, at 222.

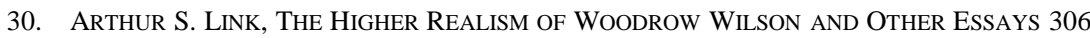
(1971).

31. See Woodward, supra note 27, at 134 (contending that President Wilson had been thinking of rural credit when he championed the Federal Reserve Act).

32. Putnam, supra note 14, at 25-26.

33. REPORT ON RURAL CREDITS, supra note 18 , at 6.
} 
mortgage business as a matter of policy. ${ }^{34}$

The momentum for more forthright help for farmers thus continued to build. The Wilson Administration incrementally changed its position, now embracing new credit legislation as part of its agenda for agriculture. $^{35}$ Some historians today list the Farm Loan Act as an illustration of the Administration's numerous means of improving agricultural production and the lives of farmers into the bargain. ${ }^{36}$ Wilson himself is said to have become "enthusiastic over its possibilities." 37

W.G. McAdoo was the key to these events. McAdoo had come to prominence as the visionary planner and manager of the great "Hudson Tube" projects in New York City. ${ }^{38}$ In Washington, he was an extraordinarily able and energetic Secretary of the Treasury. $\mathrm{He}$ shepherded the Federal Reserve Act through Congress and undertook bold measures to marshal the nation's finances during World War I. ${ }^{39}$ In addition to his duties at Treasury, McAdoo was Director-General of the Railroad Administration during the war and, as this story reveals, he was the first Chair of the Farm Loan Board. ${ }^{40}$

By the spring of 1916, McAdoo was convinced that rural credit legislation was needed and appropriate: "[T]he rates of interest on farm mortgage loans were so exorbitant, and the money-lenders so grasping, that hundreds of farming communities lived in a state of perpetual fear and poverty." ${ }^{41}$ Once committed to legislative action, McAdoo devoted his considerable talents to the project. He worked closely with congressional leaders to formulate the Act and described its adoption as one of the Administration's "crowning achievements." 42 While he was Treasury Secretary, he supported the new federally chartered banks with

\footnotetext{
34. REPORT OF THE U.S. COMMISSION, supra note 25 , at 9-11, 30.

35. Houston, supra note 28, at 207.

36. E.g., Marshall E. Dimock, Wilson the Domestic Reformer, in THE PHILOSOPHY AND POLICIES OF WOODROW WILSON 228-29 (Earl Latham ed.1958).

37. Woodward, supra note 27, at 136.

38. See Anthony Fitzherbert, The Public Be Pleased: William G. McAdoo and the Hudson Tubes, in HEADLIGHTS, June 1964, at 2 (discussing McAdoo's role in the project).

39. Mary Synon, McAdoo: The Man and His Times, a Panorama In Democracy 13141 (1924).

40. Id. at $202-03,312$.

41. William G. McAdoo, Crowded Years: The Reminiscences Of William G. McAdoo 436 (1931) [hereinafter MCADOO, CROWDED YEARS].

42. WIPRUD, supra note 18, at xiii (introduction by McAdoo). See also McAdoo to get $\$ 1$ on New U.S. Job, WASH. Times, Sept. 6, 1919, § 6 at 21 (describing McAdoo as "one of the fathers" of the Act).
} 
public funds. ${ }^{43}$ As the Farm Loan Board's first Chair, he supported the federal banks in a variety of ways. And then, after leaving the government, he helped defend the banks and tax-exempt bonds in the Smith case.

In the alternative political universe that was Congress a hundred years ago, the legislative process ground out a meaningful program in a manner that has become so rare today. Scores of bills were introduced and debated-most of them contemplating the creation of public financial institutions that would make farm loans at a favorable rate of interest. ${ }^{44}$ Constitutional objections were anticipated, and the Floor Manager in the Senate, Henry F. Hollis of New Hampshire, invited suggestions for addressing them. ${ }^{45}$ Knowledgeable members were aware that, in the great McCulloch case, John Marshall had described congressional power expansively, but had also sustained Congress's authority to establish the Second National Bank in part on the far narrower theory that the Bank was a means of handling the government's own financial affairs. In some minds, the validity of new federally chartered banks serving agriculture could best be ensured by empowering them likewise to hold public money and help administer the government's finances. Pressing this point, Senator Albert Cummins contended that the new banks would be upheld if they were given "some governmental purpose, however slight or insignificant."

When the Sixty-Third Congress failed to agree on a bill, a joint committee was named to develop a compromise plan. The joint committee's proposal was introduced in the Sixty-Fourth Congress by Hollis in the Senate and Ralph W. Moss of Indiana in the House. ${ }^{47}$ The Senate embraced it virtually as written, but the House worked it over for some months before adopting revisions. ${ }^{48}$ A conference committee reconciled the Senate and House versions. ${ }^{49}$ Prominent members explained on the floor that they would have preferred a different bill but

\footnotetext{
43. WIPRUD, supra note 18 , at xiii.

44. See W. Stull Holt, The Federal Farm Loan Bureau: Its History, Activities, AND ORGANIZATION 7-8 (1924) (describing the many bills introduced in the House and Senate).

45. See 53 Cong. ReC. 7026 (1916) (statement of Sen. Henry Hollis).

46. 53 CONG. ReC. 7246 (1916) (statement of Sen. Albert Cummins).

47. 53 Cong. ReC. 9859 (1916); 53 Cong. ReC. 7534 (1916). See generally, Buckley, FarmLoan Act, supra note 18, at 133, 136 (providing details).

48. 53 Cong. ReC. 7712 (1916) (statement of Rep. Jouett Shouse). See also WIPRUD, supra note 18 , at $4-6$.

49. H.R. REP. NO. 64-844 (1916).
} 
supported this one as an acceptable compromise. ${ }^{50}$ Both chambers adopted the conference report a few weeks ahead of the party conventions. ${ }^{51}$ There were only five negative votes in the Senate and only twelve in the House. ${ }^{52}$ President Wilson signed the new statute into law, perhaps with genuine enthusiasm, perhaps as a means of giving farmers a boost to balance legislation for the benefit of other economic sectors, and, then again by some accounts, perhaps as political expedience. $^{53}$

\section{B. The Law in the Books}

The Farm Loan Act of 1916 deserved its reputation as "the Magna Charta of American farm finance." 54 There was something in it for everybody.

To satisfy farmers and business interests advocating cheap rural credit, Sections 3 and 4 of the Act created the Federal Farm Loan Board within the Treasury Department ${ }^{55}$ and authorized it to charter Federal Land Banks ${ }^{56}$ - public cooperative institutions commissioned to make loans on agricultural land. The President filled the seats on the Board, subject to Senate confirmation. The Secretary of the Treasury (initially McAdoo), served ex officio as Chair. ${ }^{57}$ The Farm Loan Board, in turn, appointed public members of the boards of Federal Land Banks to serve along with other members chosen by farmers' associations - that is, potential borrowers themselves. ${ }^{58}$

Federal Land Banks were subject to important conditions. They could not obligate themselves beyond twenty times their capital; they could not make loans to borrowers who were engaged in a business other

50. See, e.g., 53 CONG. REC. 1570 (1916) (statement of Rep. Patrick Norton) (explaining that the bill did not conform to his "own idea of the best system of rural-credit" but endorsing it nonetheless); 53 CONG. REC. 1969-71 (1916) (statement of Rep. Warren Bailey) (declaring that the bill was not a "cure-all" but might "clear the way for more fundamental legislation").

51. Herrick, supra note 29, at 223.

52. 53 Cong. ReC. 10114 (1916); ThOMAs J. WALSh, Federal FARM LOAN ACt, S. Doc. No. 64-524, at 22 (1916); see also Putnam, supra note 14, at 42-46 (providing more details).

53. Federal Farm Loan Act, Pub. L. No. 64-158, 39 Stat. 360 (1916). See Marshall E. Dimock, Woodrow Wilson as Legislative Leader, 19 J. POL. 3, 9 (1957) (offering the second thesis); LINK, supra note 30 , at 306 (advancing the third).

54. Ben Sunbury, THE FALl OF THE FARM CREDIT EMPIRE 4 (1990).

55. $\S 3,39$ Stat. at 360-62.

56. $\S 4,39$ Stat. at 362 .

57. $\$ 3$, para. 2, 39 Stat. at 360 .

58. $\$ 3$, para. 7,39 Stat. at 361 . 
than farming; they could not loan a single farmer more than $\$ 10,000$; they could not fix the terms of mortgages at less than five or more than forty years; and they could not charge farmers an annual interest rate exceeding six per cent. ${ }^{59}$ Federal Land Banks also had enormous market advantages. They drew the lion's share of their initial capital from the Treasury Department, which committed about $\$ 9,000,000$ in start-up funds. $^{60}$ And they were able to raise additional money by issuing extraordinarily attractive bonds. Pursuant to Section 26 of the Act, bonds sold to investors were instrumentalities of the United States and exempt from federal, state, and local taxes. ${ }^{61}$

These tax exemptions enabled Federal Land Banks to raise money easily and to turn it into low-interest loans to farmers. But the economics were complicated. As a practical matter, mortgages on agricultural land were already free of most state and local taxes, because they were held by institutions that enjoyed their own tax exemptions. The exemption from federal taxes was more significant and became much more so with the adoption of the federal income tax in $1919 .^{62}$ Wealthy individuals casting about for ways to reduce their income tax bills seized upon taxexempt farm bonds (as well as Liberty Bonds and municipal bonds). ${ }^{63}$

To mollify private bankers, Section 16 of the Act authorized the Farm Loan Board also to charter Joint Stock Land Banks-privately organized financial institutions to share the field with Land Banks. The idea, variously expressed, was that bankers already in the farm mortgage business could remain in the industry if they restructured, bringing their companies under the supervision of the Board and subjecting their lending practices to federal regulation. ${ }^{64}$ The Treasury Department did

59. $§ 12,39$ Stat. at 370-71.

60. See McAdoo, Crowded YeARS, supra note 41, at 437-38 (explaining that the Treasury "advanced practically all the capital at the beginning"); see Buckley, Farm-Loan Act, supra note 18, at 142 (explaining that the limits on Land Bank loans were meant to discourage speculators and to ensure that money flowed to actual farmers).

61. Federal Farm Loan Act, $\S 26,39$ Stat. at 380.

62. E.D. Chassell, Federal Farm Loan Law, 11 LAW. \& BANKER 258 (1918).

63. Howard H. Preston, The Federal Farm Loan Case, 29 J. PoL. ECON. 433, 435, 443-47 (1921).

64. Federal Farm Loan Act, $\S 16,39$ Stat. at 374; WIPRUD, supra note 18, at 103-04; George E. Putnam, The Federal Farm Loan System, 9 AM. Econ. ReV. 51, 71 (1919). See also Victor W. Bennett, Joint Stock Land Banks in Retrospect, 20 J. FARM ECON. 857, 857-58 (1938) (describing the hope that mortgage companies "would take out charters as joint stock land banks"). Rep. Shouse explained on the floor that there were many "existing agencies through which money [was] being loaned to farmers" and that "the joint-stock land-bank feature of the bill" would "take care of those existing agencies" by making it possible for them to continue their businesses "under Government supervision, with certain very distinct and very marked benefits." 53 CONG. REC. 7713 (1916). 
not directly subsidize Joint Stock Banks by purchasing stock to set them in motion. But Treasury did buy Joint Stock bonds and, in the main, Joint Stock Banks operated like Land Banks. They, too, made long-term loans to farmers at six per cent or less; they, too, raised funds by issuing tax-exempt bonds. Private bankers successfully lobbied for provisions granting Joint Stock Banks two authorities denied to Land Banks. Joint Stock Banks could extend credit not only to farmers but to businesses with less tangible links to agriculture, and they could loan individual borrowers more than $\$ 10,000 .^{65}$ Those two capacities proved to be immensely important.

The provision for Joint Stock Banks was controversial. Farm state members of Congress objected that the very idea of Joint Stock Banks established and operated for profit was antithetical to the Act's public program. ${ }^{66}$ The addition of Joint Stock Banks essentially transformed the new structure from a single system of rural credit into a dual scheme in which Land Banks and Joint Stock Banks would compete for investors. That competition would drive up the interest rates for bonds, which would inevitably drive up the rates farmers paid for mortgage loans, as well - the very interest rates it was the point of the Act to drive down. ${ }^{67}$ Yet the private banking interests pressing the Joint Stock option held the stronger political hand. In the Smith litigation, Bullitt would marginalize Joint Stock Banks as "an evident after-thought."68 Hardly. Acceptance of Joint Stock Banks as a concession to private bankers was the political price for an enacted law. ${ }^{69}$ Rank and file members understood this and acquiesced whether they liked it or not. An amendment in the House that would have deleted the provision on Joint Stock Banks was defeated by an overwhelming majority. ${ }^{70}$

The Act also contained provisions that Cummins and others insisted upon for the sole purpose of fortifying both kinds of federally chartered banks against constitutional attack. Section 6 authorized the Secretary of the Treasury to designate Land Banks and Joint Stock Banks as

65. Federal Farm Loan Act, $\S 16$, para. 8, 39 Stat. at 374 .

66. 53 Cong. ReC. 7979 (1916) (statement of Rep. William Oliver); 53 Cong. ReC 7982 (1916) (statement of Rep. David Finley). See also Buckley, Farm-Loan Act, supra note 18, at 143 (arguing that the Joint Stock Banks would "provide a very unnecessary competition to the cooperative system").

67. 53 Cong. REC. 7992 (1916) (statement of Rep. Dick Morgan).

68. Appellant's Revised Brief, supra note 26, at 15.

69. 53 CONG. REC. 10040, 10113 (1916) (statements of Reps. Percy Quin \& Asbury Lever). See Bennett, supra note 64, at 858 (calling the inclusion of the private banks "politically expedient").

70. 53 CONG. REC. 7995 (1916). 
depositaries of federal money and to employ them as financial agents of the United States. ${ }^{71}$ Other provisions empowered the new banks to buy and sell United States bonds ${ }^{72}$ and required Land Banks to hold government bonds as at least five per cent of their capital. ${ }^{73}$ These elements were manifestly incidental to the primary purpose of the Act, which was to forge a new credit system for American agriculture. Yet Congress promoted them as important additional objectives - to the point of listing them explicitly in the formal title to the Act: "An act to provide capital for agricultural development, to create standard forms of investment based upon farm mortgage, to equalize rates of interest upon farm loans, to furnish a market for United States bonds, to create government depositaries and financial agents for the United States, and for other purposes." 74

Contemporaneous reactions to the Farm Loan Act varied. In hindsight, it is difficult to separate genuine assessments of the new federal framework from ideologically charged political objections. At least some public statements may best be understood as so much posturing in hopes of influencing Congress to think and act again. In his opening speech to the FMBA convention in 1917, the Association's president, F.W. Thompson, condemned the Act as a transparent "bid for the farmer vote." "75 By Thompson's account, the Act was economically unsound in that it ignored market conditions that should properly determine the rate of return and attempted to "control by law a flat loaning rate of interest." ${ }^{, 76}$ The purpose of the Act, he declared, was to "strike a body blow to organized farm mortgage bankers, expecting the latter to succumb and thus give the Federal Banks a practical monopoly on the farm mortgage business." 77

\section{The Law in Action}

Actual experience under the Act was mixed. The Farm Loan Board established twelve Land Banks, and they got off to a fair start early in

\footnotetext{
71. Federal Farm Loan Act, Pub. L. No. 64-158, § 6, 39 Stat. 360, 365 (1916).

72. $\S 13$, para. 8,39 Stat. at 372 .

73. § 5, para. 7, 39 Stat. at 364 .

74. § 1, para. 1, 39 Stat. at 360. But see Buckley, Farm-Loan Act, supra note 18, at 144 (defending these provisions as mechanisms by which Treasury might assist federal banks having difficulty meeting their short-term obligations).

75. 1917 FMBA PROCEEDINGS, supra note 20, at 31.

76. Id. at 31 .

77. Id. at $31-32$.
} 
1917-effectively making loans from public funds and then finding private investors willing to buy tax-exempt bonds to keep the money flowing. ${ }^{78}$ But private investments declined in the spring and summer. ${ }^{79}$ The war in Europe was obviously a factor. Impending American involvement was unsettling in itself. In addition, tax-exempt Liberty Bonds competed with farm bonds already on the market. ${ }^{80}$

The situation spawned three undertakings meant to stimulate farm bond purchases. Congress authorized the Treasury Department to pump more public cash into Land Banks. ${ }^{81}$ Secretary McAdoo made arrangements with four large houses to market the bonds. ${ }^{82}$ And, most important for our purposes, the four bond houses obtained a legal opinion assuring investors that the tax exemptions that made farm bonds attractive would be upheld as constitutional.

To make the case for the validity of the bonds convincingly, the bond agents went to an unimpeachable source: Charles Evans Hughes. The former Governor of New York and Associate Justice of the Supreme Court was rock solid. ${ }^{83} \mathrm{He}$ had served with most of the justices who would determine the validity of the Act, he was widely regarded as conservative where federal power was concerned, and he had just lost the presidential election to Wilson and thus had no reason to love any innovative program embraced by the Administration, however dubitante. ${ }^{84}$ For all this, Hughes told the bond houses precisely what they needed and wanted investors to hear. In his considered opinion, the Land Banks and tax-free bonds authorized by the 1916 Act could rest on either of two congressional powers. ${ }^{85}$

First, Congress could tax (and thus spend) to provide for the general

78. 1920 Secretary OF The Treasury ANN. ReP. 185-86 [hereinafter 1920 Treasury REPORT].

79. Id. at 186 .

80. Id.

81. Id. at 187.

82. First Annual Report Of The Federal Farm LoAn Board, H.R. Doc. No. 65-714, at 17-18 (1918) [hereinafter FIRST ANNUAL REPORT] (explaining the need to use the bond houses); Henry Hall, Liberty Bonds, Farm Loan Bonds and the General Market, 11 LAW. \& BANKER 236, 240 (1918) (reporting the arrangements).

83. See Robert F. Wesser, Charles Evans Hughes: Politics And Reform In New York 1905-1910 (1967) (describing Hughes's career in New York); DeXter PERKINS, Charles Evans Hughes AND American DemOcratic STATESMANShIP (1956) (describing his tenure as an Associate Justice).

84. Six sitting Justices had been on the Court when Hughes was an Associate Justice-Holmes, Day, Van Devanter, McReynolds, Pitney, and White. Brandeis had joined the Court just as Hughes was leaving.

85. Charles E. Hughes, Federal Land Bank Bonds 30-31 (1917). 
welfare - in this instance by stimulating agriculture to ensure an ample food supply. ${ }^{86}$ In turn, Congress could establish Federal Land Banks as a "necessary and proper" means of distributing public funds for the purpose. ${ }^{87}$ Hughes invoked Chief Justice Marshall's capacious expressions of congressional power in McCulloch. ${ }^{88} \mathrm{He}$ acknowledged that private borrowers and investors might benefit. But he insisted that the government's involvement in the Land Banks and the use of public funds to capitalize them over the near term sufficiently brought their existence and activities within the power to disburse public treasure for the common good. ${ }^{89}$ Second, Congress could borrow money on the credit of the United States and, again, could create Land Banks as "necessary and proper" instruments for facilitating the government's fiscal operations. ${ }^{90}$ On this second point, Hughes cited the provisions that had been inserted in the Act to parry any constitutional challengenamely, the sections authorizing Treasury to designate Land Banks as depositaries of government funds, empowering Land Banks to trade in United States securities, and requiring them to hold government bonds. ${ }^{91}$ Here, too, $M c C$ ulloch provided all the precedential authority required.

If it was once established that Congress had power to create the Land Banks, Hughes maintained that the validity of tax exemptions for farm bonds issued by those institutions followed as a matter of course. Congress was free to suspend federal taxes as an incident of its authority to impose taxes in the first place. ${ }^{92}$ In one last effort to reassure private investors, Hughes offered that by authorizing farm bonds to be sold on the promise that they would not be taxable, Congress had committed the government to private purchasers and could not renege. ${ }^{93}$ Anyone holding farm bonds could rest easy; anyone considering a future purchase could proceed with confidence.

The Administration's efforts to shore up the Land Banks' capital and Hughes's widely circulated endorsement of their validity may have had some effect. In early 1919 and into 1920, the Land Banks made loans to

86. U.S. CONST. art. I, $\S 8$, cl. 1 .

87. U.S. CONST. art. I, $\S 8$, cl. 18.

88. Hughes, FedERAL LAND BANK BONDS, supra note 85, at 11.

89. Id. at 31 .

90. Id. at 30. U.S. ConsT. art I, § 8, cl. 18; U.S. ConsT. art. I, § 8, cl. 2.

91. Hughes, Federal LAND BANK Bonds, supra note 85, at 31-35. See also supra text accompanying notes $45-46,71-73$.

92. Hughes, FEDERAL LAND BANK BONDS, supra note 85, at 53.

93. Id. at 54 . 
farmers on a massive scale. ${ }^{94}$ Yet the party was short-lived. When the Smith suit was initiated, the investment environment was unsettled yet again. Moreover, the Land Banks encountered competition from their more private-looking cousins, Joint Stock Banks authorized by the Act to operate in the same precincts.

The Farm Loan Board moved more deliberately with respect to Joint Stock Banks, chartering only five in the early going. There is evidence that the Board was not enamored by Joint Stock Banks and saw them for what their detractors in Congress had always claimed they were: unwarranted private competitors to Land Banks run by the Board's appointees and farmers themselves. ${ }^{95}$ But the Board professed not to be "particularly concerned" whether Land Banks or Joint Stock Banks supplied farmers with needed loans. ${ }^{96}$ And in due course it acted on more applications filed by private bankers who resigned themselves to the new federal framework. James F. Toy told the FMBA that his finance company in Sioux City, Iowa had applied for a charter and urged his colleagues to do the same. ${ }^{97}$ Toy insisted that, sooner or later, bankers would have to recognize that they had "the United States Government to compete with" and that (to coin a phrase) resistance was futile. $^{98}$ Their only chance was to accept the Joint Stock model and try to make it profitable. ${ }^{99}$ Before long, there were enough Joint Stock Banks to form their own organization. The Secretary of the American Association of Joint Stock Land Banks defended bankers like Toy for seeing that "the day of the farm-mortgage broker, with his high rates and excessive commissions, was ended."100

For a while, private bankers who obtained Joint Stock charters were extremely successful. When the complaint in Smith was filed in July of 1919, twenty-one Joint Stock Banks were up and running notwithstanding the war, concentrating their operations in the richest agricultural states. The reasons for this success are debatable. But it seems fair to say that Joint Stock Banks were able to capitalize on their

\footnotetext{
94. 1920 TREASURY REPORT, supra note 78, at 186.

95. Bennett, supra note 64 , at 864 .

96. FIRST ANNUAL REPORT, supra note 82, at 21-22 (contending that critics misconstrued the Board's discouragement of fraudulent promotions by some private banks).

97. 1917 FMBA PROCEEDINGS, supra note 20, at 66-67.

98. Id. at 66.

99. Id.

100. Exemption of Federal Farm Loan Bonds from Taxation: Hearings on S. 3109 Before the Comm. on Banking and Currency, 66th Cong. 46 (1920) [hereinafter Hearings on S. 3109] (statement of W.W. Powell).
} 
advantages over Land Banks - that is, their ability to make larger loans to borrowers other than farmers. ${ }^{101}$ By some accounts, those borrowers included "landlords and speculators." 102 Joint Stock Banks soon occupied nearly half the national market for agricultural mortgages and were proving to be the very menace their opponents had anticipated. ${ }^{103}$ Introduced as a politically necessary sop to protesting private bankers, they now threatened to starve out both private bankers who refused to follow Toy's lead and the centerpiece institutions created by the Act: publicly governed Federal Land Banks. ${ }^{104}$

Even the comparative fortunes of Joint Stock Banks could not dispel opposition from other private bankers, who persisted in putting Joint Stock Banks in the same category with Land Banks. A member of the Farm Loan Board, Charles E. Lobdell, reminded the FMBA that Joint Stock Banks had been added to the mix for the very purpose of allowing private banks a place in the new system. ${ }^{105}$ Yet many bankers wanted more - namely, the ability to maintain their existing businesses and to register as Joint Stock Banks, thus to operate as they always had (without much federal supervision), now with the tax advantages that federal law attached to Joint Stock status. ${ }^{106}$ There was some question whether the 1916 Act would permit private bankers to wear two hats, though some bankers managed to finesse the question by organizing Joint Stock Banks as affiliates. ${ }^{107}$

Meanwhile, the Farm Loan Board remained of two minds. On the one hand, the Board continued to encourage private bankers to cooperate, even proposing amendments to the Act to make the Joint Stock model more acceptable. ${ }^{108}$ On the other, the Board declared that Land Banks

101. See Third Annual Report Of The Federal Farm Loan Board, H.R. Doc. No. 66553, at 3 (1920) [hereinafter THIRD ANNUAL REPORT] (describing the growth of Joint Stock Banks in 1919).

102. Preston, supra note 63, at 451.

103. The Farm Loan Board reported that the percentage of loans made by Joint Stock Banks had increased from $15 \%$ to $38 \%$ during 1919. THIRD ANNUAL REPORT, supra note 101, at 3 . The Board itself suggested that the Joint Stock Banks had primarily drawn business away from the "old line mortgage agencies." Id. at 4.

104. See generally George E. Putnam, Recent Developments in the Federal Farm Loan System, 11 AM. ECON. REV. 427 (1921).

105. 1917 FMBA PROCEEDINGS, supra note 20, at 53.

106. Id. at 62-65 (recording an inconclusive exchange between Lobdell and unidentified bankers).

107. Bennett, supra note 64 , at 859 .

108. Want Banks to Join Farm Loan System, N.Y. TimES, Dec. 24, 1917, at 14 (reporting the Board's endorsement of a reduction in the capital requirement for Joint Stock Banks). 
alone could supply all the farm mortgage loans the country required, recommended that Land Banks, too, should be authorized to make large loans, and endorsed a bill by Senator Reed Smoot of Utah that would withdraw the authority of Joint Stock Banks to issue tax-exempt bonds. ${ }^{109}$ The Board's apparent disdain for Joint Stock Banks, in turn, further discouraged private bankers. Even if the other doubts and concerns about obtaining Joint Stock charters were overcome, bankers now feared that if they registered as Joint Stock Banks, they would be at the mercy of hostile regulators. ${ }^{110}$

Through it all, the specter of the Supreme Court's coming decision in the Smith case was a pervasive force. ${ }^{111}$ Bankers were (or claimed to be) unnerved by the choice with which they were presented. If they accepted Joint Stock charters, they, too, would be required to make long-term loans at artificially reduced rates. Then, if it turned out that key features of the Act were unconstitutional (read the tax exemptions that made low rates feasible), they would be left holding the bag as the farm loan industry in its entirety collapsed around them. ${ }^{12}$ Opinions among private bankers thus converged on F.W. Thompson's position that "the only alternative left ... [was] to bring appropriate constitutional test suits as quickly as possible affecting both Federal Farm Loan Bank Bonds and the bonds of joint stock banks as well." 113

By all accounts, the constitutional challenge in Smith wrecked the rural financial system established by the Act. Sales of bonds dropped precipitously after the suit was filed. ${ }^{114}$ The Farm Loan Board directed that all applications for loans be taken subject to a favorable decision. ${ }^{115}$ When loan commitments on that basis accumulated, Treasury itself purchased more bonds "to meet the emergency confronting the system." 116 Yet, in the end, the federal banks were forced to suspend operations entirely. Whatever would have been the fate of federally

109. Hearings on S. 3109, supra note 100 (statement of W.W. Powell); see 1920 TrEASURY REPORT, supra note 78, at 188-89 (explicitly recommending the repeal). See also Putnam, supra note 104, at 436 (contending that public support for all tax exempt bonds declined after the war).

110. Putnam, supra note 104, at 434.

111. 1920 TREASURY REPORT, supra note 78, at 188 (reporting that Joint Stock Banks were affected by the same legal uncertainties that undermined Federal Land Banks).

112. 1917 FMBA ProceEdings, supra note 20, at 88 (statement of F.W. Thompson); id. at 71 (statement of Levering Moore).

113. Id. at 20 , at 32 (statement of F.W. Thompson).

114. 1920 TREASURY REPORT, supra note 78, at 186.

115. Id.

116. Id. at 187 . 
chartered land banks and tax-exempt farm bonds apart from constitutional doubts, the persistence of uncertainty in the graphic form of an actual lawsuit put the entire program on hold for the year preceding the Court's decision. ${ }^{117}$

\section{THE TEST CASE}

\section{A. Initial Steps}

The FMBA decided against making litigation over the Farm Loan Act a formal part of its agenda. James Toy warned that the public would view a legal challenge as "purely selfish"-an attempt to obstruct Congress's effort to ensure that farmers could borrow money at a fair rate of interest. ${ }^{118}$ Others acknowledged that it would be bad business to antagonize both farmers and federal regulators at the same time. ${ }^{119}$ Some suggested that a "friendly" test suit could be brought, purporting to seek only clarification of the legal issues. ${ }^{120}$ The consensus was that members should support litigation individually, and member banks acting for themselves readily pledged subscriptions to pay the expenses of a test suit. ${ }^{121}$ In the event, funds raised from individual banks were channeled back through the FMBA, which issued a check directly. ${ }^{122}$

The FMBA's incoming President orchestrated the effort. J.E. "Daddy" Maxwell had been in the farm mortgage business all his adult life. He had started with a partnership in the tiny village of Paola, Kansas and had built the Maxwell Investment Company into a regional powerhouse. ${ }^{123}$ Maxwell told the FMBA that bankers were not alone. Other "large organizations" were aware of their plight and "promised support" for the "fight." 124 The identity of those "organizations" is not clear, but it is a fair guess that Maxwell meant the country's great

117. Fourth Annual Report Of The Federal Farm Loan Board, H.R. Doc. No. 66-998, at 2 (1921); see Woodward, supra note 27, at 135.

118. 1917 FMBA PROCEEDINGS, supra note 20, at 100.

119. Id. at 104-05.

120. Id. at 204-05 (statement of W.M. Fitch).

121. Id. at 149-52 (general discussion).

122. The receipts of Bullitt's law firm show a \$6,500 payment from the FMBA on November 11, 1920. Letter from Shirley Harmon, Filson Historical Society, to author (undated) (on file with author).

123. Mr. Corwin's Remarks, in Annual Address by President J.E. Maxwell at Seventh Annual Convention of the Farm Mortgage Bankers Association of America 11, 11 (1920) (summarizing Maxwell's career).

124. Criticise Farm Loan Bank, N.Y. Times, Sept. 24, 1919, at 29. 
insurance houses. Robert L. Cox, President of the Association of Life Insurance Companies, addressed the FMBA in 1919. ${ }^{125}$ Cox was the life insurance industry's chief spokesman in the period and took a special interest in agricultural finance. At his own firm, Metropolitan Life in New York, Cox had charge of the Farm Loan Division. ${ }^{126}$

Maxwell and other bankers in Kansas formed a committee to undertake litigation and enlisted the help of the FMBA secretary, H.M. Hanson, in obtaining counsel to do the work. Hanson initially approached John G. Johnson in Philadelphia, then perhaps the nation's preeminent corporate litigator. Johnson declined and later advised a banking journal that a constitutional attack on the Act would fail. ${ }^{127}$ Hanson then turned to Charles Evans Hughes - the very man destined to defend the constitutionality of what Congress had wrought. ${ }^{128}$ At this early stage, Hughes was willing to represent private banks. But he declined to name a fee until the litigation was complete. The conservative Kansas bankers balked at an open-ended arrangement. While they debated among themselves, the bond houses employed Hughes to give his personal legal opinion on the validity of the Act. Soon thereafter, Hughes's opinion appeared, anticipating and refuting the constitutional challenge.

It was time for the bankers to look elsewhere. Maxwell explained that they sought the recommendation of the "the largest investors in the country," "129 which, again, almost certainly meant life insurance companies. Robert Cox sent a copy of Hughes's opinion to William Marshall Bullitt in Louisville and asked for Bullitt's "mind on the question." ${ }^{130}$ Bullitt was known to insurance lawyers nationally because of his successful handling of cases in Kentucky. He had recently made

125. Farm Mortgage Bankers to Meet, N.Y. TimEs, Sept. 18, 1919, at 25. The content of Cox's speech cannot be retrieved. Few FMBA records after 1918 have survived.

126. The general counsel at New York Life later complimented Bullitt on his brief in the Smith case and declared that he had no doubt that "[i]f the question had come up in Marshall's day" the Act would have been invalidated. Letter from James H. McIntosh, General Counsel, New York Life Insurance Company, to William M. Bullitt (Nov. 5, 1920) (on file with Filson Historical Society).

127. 1917 FMBA PROCEEDINGS, supra note 20, at 91 (statement of J.E. Maxwell) (reporting the contact with Johnson); Validity of the Federal Farm Loan Act, 11 LAW. \& BANKER 425, 425 (1919) (reporting Johnson's opinion). See generally Gerard J. St. John, John G. Johnson: Giant of the Philadelphia Bar, 69 THE PHILA. LAW. no. 4 (2007) (describing Johnson's career and reputation), available at http://www.philadelphiabar.org/page/TPLWinter07Johnson?appNum=1.

128. 1917 FMBA PROCEEDINGS, supra note 20, at 91 (statement of J.E. Maxwell).

129. Id.

130. Letter from Mary Weist to William M. Bullitt (July 9, 1917) (on file with Filson Historical Society) (informing Bullitt of the message from Cox). 
an important speech to the Association of Life Insurance Counsel. On this occasion, his response was evidently satisfying. The bankers retained him, seconded by Frank Hagerman, a prominent railroad lawyer in Kansas City who had himself been an assistant in the Solicitor General's office. ${ }^{131}$ Bullitt responded publicly to Hughes in a speech to the FMBA the following year, the text of which was also published and circulated. ${ }^{132}$

A precise account of the suit's development cannot be recovered. ${ }^{133}$ But an approximation of the story can be inferred from the bits and pieces of documentary evidence that can be found. Fortunately, Bullitt was an inveterate note-taker. His diary strongly suggests that Cox directed the bankers to Bullitt and that Maxwell steered Bullitt to the Kansas City Title \& Trust Company and Charles Smith. ${ }^{134}$

We know something about Charles E. Smith and the Trust Company. In the last years of the nineteenth century and the early part of the twentieth, the mortgage lending industry labored to develop a fast, cheap, and reliable system for verifying land titles. The most promising possibility was title insurance, which protected investors against mistakes in title searches. The point of insurance was pooling risks, and as small abstract companies became insurers they naturally tended to merge. In 1915, the Kansas City Title \& Trust Company was formed from a half dozen smaller firms. ${ }^{135}$ John Henry Smith had been vice president of one of the firms, Union Abstract \& Guaranty Company. He became secretary of the new company, and, in 1919, he was named

131. DAVIS, supra note 10, at 87; 1917 FMBA ProceEDINGS, supra note 20, at 91 (statement of J.E. Maxwell).

132. William M. Bullitt, The Validity of the Federal Farm Loan Act, Fifth Annual Convention of the Farm Mortgage Bankers Association (Sept. 19, 1918). A letter from Bullitt's secretary, Mary Weist, referred to the possibility that the FMBA might print a "new edition" of his speech. If another edition came out, Bullitt instructed Weist to order as many as 200 additional copies. Letter from Mary Weist to William M. Bullitt (Nov. 26, 1918) (on file with Filson Historical Society).

133. Bullitt's file on the Smith case has not survived. It may have been burned in a fire at the family home in 1943 or discarded after a flood in the basement. Letter from Shirley Harmon, Filson Historical Society, to author (March 19, 2011) (on file with author). Hagerman's file is not among his papers at the Spencer Library, University of Kansas, Lawrence, Kansas.

134. On May 12, 1917, Bullitt wrote to Cox about his employment by the Farm Mortgage Bankers Association. On May 19 and 29, he wrote to Cox again and also to J.E. Maxwell. On July 9, he wrote again to Maxwell and to Hagerman in Kansas City. Through the remainder of 1917, he wrote to Maxwell and Hagerman fairly regularly. Bullitt was in Europe much of 1918. His correspondence with Maxwell and Hagerman resumed on his return and continued through 1919 (as the suit was launched in Kansas City) and 1920 (as the appellate process played out). Entries from William Marshall Bullitt's Daily Record (undated) (on file with Filson Historical Society).

135. National Register of Historic Places Registration Form: Kansas City Title \& TRust Building, Mo. DeP'T OF NATURAL ResourCES (May 5, 2005). 
president. His brother, Charles, became a vice president. ${ }^{136}$

From the outset, the Trust Company was noted for rapid growth, fueled by innovation. The company was the first of its kind to extend operations to other states, the first to frame a standard policy limiting liability for title forgeries, and the first to construct facilities adequate for storing title documents that might be needed to answer claims. Most important for our purposes, the Trust Company pioneered the business of supplying title insurance to banks making loans to farmers throughout the Midwest and the South. ${ }^{137}$

A title insurance company made money by providing insurance that would foster farm loans - not, presumably, by purchasing bonds issued to raise capital for extending loans. But the Trust Company was also chartered to engage in "the business of acting ... as agent, executor, administrator, guardian, curator, trustee and generally in fiduciary capacities."138 Both Smiths were well known in Kansas City financial circles. In addition to his position at the Trust Company, John Henry was president of McCrae Securities and a director of the Security National Bank. ${ }^{139}$ It is possible that the Trust Company itself made agricultural loans. But there is no surviving evidence that the company was among the mortgage banks that retained Bullitt. Its name did not appear on the list of the FMBA's members in 1917. It is more likely that the Trust Company became involved because of its longstanding interest in and association with banks that did lend money to farmers. ${ }^{140}$

The shareholder action in Smith was a friendly matter. Charles Smith was not a disgruntled shareholder. He was a vice president of the Trust Company. Some observers apparently believed that Charles acted alone in bringing the action. One newspaper asked whether "one individual" should be permitted to initiate a lawsuit that could "injure

136. Id.

137. Title Firms Join Hands: Abstractors Merge in a 3-4 Million Dollar Company, KANSAS CITY STAR, May 16, 1915, at 2b.

138. Bill in Equity at 2, Smith v. K.C. Title \& Trust Co. (W.D. Mo. July 19, 1919) (No. 212).

139. George Kreel \& John Slavens, Men Who Are Making Kansas City: A BIOGRAPHiCAL DiRECTORY 146 (1902); 3 WALTER BARLOW STEVENS, CENTENNIAL History of Missouri (The Center State): One Hundred Years In The Union, 1820-1921, at 189-90 (1921).

140. Two members of the Trust Company's board in 1921, Jesse P. Crump and W.T. Kemper, were also officers of other financial institutions, Fidelity National Bank \& Trust Company and Commerce Trust Company, respectively, which were members of the FMBA. KANSAS CiTY TITLE \& TRust COMPANY, COMPANY OfFICERS (1921) (on file with Missouri Valley Special Collections, Kansas City Public Library). 
millions" of farmers. ${ }^{141}$ More knowledgeable critics smelled a rat. After the Supreme Court decision, one journal claimed that there had always been "a serious question of the bona fides of the plaintiff Smith who represented in fact the Farm Mortgage Bankers Association."142 The case had proceeded, it was said, on the basis of a "state of facts" prepared to disguise "the dirt on the hands of the plaintiff seeking equity." 143 There really is no question about Charles. He was a shill for the mortgage banks sponsoring the suit.

The Trust Company's attorney, Justin DeWitt Bowersock, was a prominent local political figure and himself a member of the Trust Company's board. There is no evidence that he deliberately defaulted in his job. But he candidly acknowledged that he deferred to Hughes, Wickersham, and McAdoo to marshal the defense. According to Bowersock, the Trust Company's role was "secondary" to the "paramount" interests of the intervenors and the government itself. ${ }^{144}$ The "titular defendant" actually appeared "rather as a casus belli than as a chief belligerent." "145 Then again, no one who participated in Smith made any effort to frustrate the suit on procedural or jurisdictional grounds. Everyone acknowledged the convenient litigation tool a shareholder action supplied for getting to the merits.

\section{B. The Form of the Action}

Bullitt's first order of business was to construct a civil action with the best chance of achieving an adjudication of the constitutional questions he wanted to raise. $\mathrm{He}$ might have generated some rudimentary dispute between one of his client banks and a Federal Land Bank or Joint Stock Bank - for example, a disagreement over a particular mortgage foreclosure. But a suit of that kind might not have implicated the federally chartered bank's constitutionality or, what was most important, the validity of the tax exemptions for farm loan bonds. The constitutionality of the Second National Bank had been presented in McCulloch, but there, as in the Osborn case, ${ }^{146}$ the Bank was the moving

\footnotetext{
141. W.J. Bryan, Time for Remedy, 21 THE COMMONER, no. 3, at 2 (1921).

142. Land Banks Win, 14 LAW. \& BANKER 69, 69-70 (1921).

143. Id

144. Brief of Appellee, Kansas City Title and Trust Co., at 2, Smith v. K.C. Title \& Trust Co., 255 U.S. 180 (1921) (No. 199) (brief on reargument).

145. Id.

146. Osborn v. Bank of the United States, 22 U.S. (9 Wheat.) 738 (1824).
} 
party and its ability to engage in litigation logically entailed its lawful existence. $^{147}$

Bullitt might have persuaded state or local tax officials to sue a bond holder who claimed an exemption under the Act. But a public action would have required tacit agreement, and there was a risk of losing control. Moreover, farm bonds were primarily appealing to investors because of the exemption from federal income taxes. It is unlikely that the Treasury Department would have cooperated in a suit challenging the constitutionality of tax rules written by Congress. Recall that Secretary McAdoo had a hand in drafting the Act and thereafter promoted federally chartered banks with great energy. ${ }^{148}$

In the event, Bullitt framed the suit as a shareholder action by Charles Smith against his own corporation. In part, the shareholder device may have been implemented to mask the interests actually behind the attack on the Farm Loan Act. Yet there are also substantive explanations. The shareholder suit in Smith was an ingenious means of marshaling all the constitutional questions touching the Act for challenge in a single stroke and, into the bargain, litigating that challenge in federal court. Bullitt almost certainly chose the shareholder model for these reasons, albeit there is no surviving documentary evidence of what he actually thought and did.

It turns out, though, that he scarcely had to develop the idea on his own. Corporations had been using shareholder suits in this way for decades. ${ }^{149}$ There is a story behind the form of the action in Smith, but it is not confined to Smith alone. It extends to a pattern of shareholder suits employed to generate federal jurisdiction for corporate litigation attacking social welfare legislation. ${ }^{150}$ Corporations (including banks,

147. In Bank of the United States v. Planters' Bank, 22 U.S. (9 Wheat.) 904 (1824), the Court assumed only that some federal questions regarding the Bank's status could potentially be placed in issue. Then again, the defendant corporation in Planters' Bank raised an unsuccessful constitutional defense.

148. See supra text accompanying notes 41-42. A bondholder could scarcely sue tax collectors to establish that farm bonds could not be exempted from taxation-even if there had been a procedural mechanism for taking the initiative more than thirty years before the Declaratory Judgment Act. Nor was there any viable argument that a bondholder could go against the Farm Loan Board or the federally chartered banks, contending that the bondholder would suffer financial losses if the bonds turned out to be taxable after all. As explained below, factual harm alone was insufficient for standing at the time. See infra text accompanying notes 156-59. Bullitt would have been hard pressed to show that federal officials and operators committed fraud simply by making farm bonds available for sale.

149. Evan Tsen Lee, Judicial Restraint in America: How the Ageless Wisdom of the FEDERAL Courts WAS INVENTED 69-70 (2010).

150. Id. (citing Cotting v. Kansas City Stock Yards Co., 183 U.S. 79 (1901) (challenging rate 
especially banks) did this all the time. The Supreme Court knew they were doing it and expressed misgivings. But on the whole the Court acquiesced. ${ }^{151}$

Corporations' use of shareholder suits to advance constitutional claims overlaps with another narrative: corporations' exploitation of diversity jurisdiction to obtain the benefits of the general common law applied in the federal courts prior to the Erie decision in $1938 .^{152}$ The Supreme Court indulged corporate litigation in diversity on a variety of fronts. Eventually, however, the Court discarded the very idea of general law and held that federal courts sitting in diversity would ordinarily apply the decisional law of the state concerned-however unfavorable that law might be to corporate interests. ${ }^{153}$ By contrast, the Court was never persuaded that federal jurisdiction was unwarranted to address constitutional claims. ${ }^{154}$

The Smith case demonstrates that a shareholder action could open the door to the federal courts for the adjudication of a corporate attack on a federal program. The shareholder model was a means of satisfying three prerequisites for invoking the power of the federal judiciary: standing to appear in an Article III court, the federal court's equitable jurisdiction to extend injunctive relief, and the court's statutory subject matter jurisdiction to entertain the action. As things turned out, Bullitt probably worked harder than necessary to frame precisely the right shareholder suit for these purposes, given that everyone involved wanted the litigation to go forward. Still, a full understanding of what happened demands attention to the world as Bullitt saw it in 1919 and the strategy he devised to obtain the benefits of the shareholder device for his real clients - the mortgage banks paying his fee.

regulations)).

151. See id. See also Deborah A. Demott, Shareholder Derivative Actions: Law And PRACTICE 1-8 to 1-14 (2010).

152. See Erie R.R. Co. v. Tompkins, 304 U.S. 64, 78 (1938) (declaring that " $[\mathrm{t}]$ here is no federal general common law").

153. See Edward A. Purcell, JR., Litigation and Inequality: Federal Diversity JURISDICTION IN INDUSTRIAL AMERICA, 1870-1958, 22-27 (1992) (describing corporations' preference for diversity jurisdiction and the federal common law); EDWARD A. PURCELL, JR., BRANDEIS AND the Progressive Constitution: ERIE, THE Judicial Power, AND the Politics OF THE FEderal COURTS IN TwENTIETH-CENTURy AMERICA 65-66, 77-79 (2000) [hereinafter PURCELL, BRANDEIS AND THE PROGRESSIVE CONSTITUTION] (explaining that corporations "heralded the uniformity of the federal common law" while Progressives opposed jurisdictional rules that favored corporations).

154. PuRCELl, BRANDEIS AND the Progressive Constitution, supra note 153, at 44-45. 


\section{Standing}

Today, a private mortgage bank would probably be able to mount a constitutional challenge to a statute like the Farm Loan Act. The plaintiff bank could complain that federally chartered banks issuing taxexempt bonds cut into the private bank's profits. That competitive injury would satisfy the basic constitutional requirement for standing. Moreover, today, the statute itself would probably defuse nonconstitutional standing barriers by expressly authorizing private suits by designated plaintiffs against either the federal agency administering the program or an entity-public or private-actually conducting the activities said to harm the complaining parties. Then, too, the Administrative Procedure Act now authorizes judicial review at the behest of a plaintiff who is "[adversely affected] or aggrieved by agency action"- a category of factual interests that includes the interest in avoiding competition. ${ }^{155}$

But when the Smith case was initiated, the requirements for standing were quite different. A party seeking access to an Article III court had to assert injury to a legal interest, which was understood to mean a violation of a legal right. Injury from competition, however real, was inadequate. ${ }^{156}$ The leading decision on the point, Alabama Power Co. v. Ickes,${ }^{157}$ involved a private utility company complaining of competition from public power plants. ${ }^{158}$ It would be another year beyond Alabama Power, and twenty beyond Smith, before the Supreme Court would be satisfied with factual injury alone. ${ }^{159}$

It is debatable whether the "legal interest" test for standing in Alabama Power was grounded in Article III and the separation of powers, as opposed to judicial discretion or perhaps a combination of constitutional and prudential considerations. The modern Court has voiced the former view. ${ }^{160}$ Yet even if the "legal interest" limitation was

155. Ass'n of Data Processing Serv. Orgs. v. Camp, 397 U.S. 150, 153 (1970).

156. See Cass R. Sunstein, Standing and the Privatization of Public Law, 88 ColuM. L. Rev. 1432, 1436 (1988).

157. 302 U.S. 464 (1938).

158. Id. at 464-65; accord Tenn. Elec. Power Co. v. Tenn. Valley Auth., 306 U.S. 118, 140-41 (1939) (denying private power companies standing to attack the Tennessee Valley Authority).

159. See FCC v. Sanders Bros. Radio Station, 309 U.S. 470 (1940).

160. See Sierra Club v. Morton, 405 U.S. 727, 733 \& n.4 (1972) (describing Alabama Power as an "extreme form" of the then-prevailing view that only a "legal interest" or a "legal wrong" satisfied the "constitutional requirements of standing"); but see LEE, supra note 149, at 77 (contending that the Court in Alabama Power itself conceived that it rested on a "policy of judicial restraint"). 
non-constitutional and thus something Congress could relax, there was no provision in the 1916 Act permitting competing banks to sue the Farm Loan Board or the federally chartered banks. Nor was there any freestanding means of seeking judicial review of the Act itself or actions taken under its aegis. The Administrative Procedure Act was a halfcentury away. ${ }^{161}$

The 1916 Act did contain a boilerplate "sue and be sued" provision. ${ }^{162}$ But nothing suggests that anyone thought that clause authorized suits by private banks. The "sue and be sued" clause merely established Federal Land Banks as juridical entities capable of participating in litigation as though they were natural persons. ${ }^{163}$ The only other provision in the Act arguably bearing on litigation was the severance clause, which stated that a judgment by "any court of competent jurisdiction" holding some part of the Act invalid would have no effect on the remaining provisions. ${ }^{164}$ The premise of that clause was that someone could challenge the Act's validity in court by some means. But obviously the severance clause did not itself authorize litigation.

Bullitt's difficulty regarding standing, accordingly, was that his real clients - private mortgage banks - had no legal rights to assert against the parties whose behavior was diminishing their profits: the Farm Loan Board and the Land Banks and Joint Stock Banks. Bullitt certainly meant to contend that the Board and the federally chartered banks were acting without lawful authority. And he in particular meant to argue that the tax exemptions for the bonds they issued were invalid. But there was no intelligible argument that the actions of federal officers and operators constituted a breach of any legal duty owed in particular to private bankers.

This is where the shareholder suit model came into play. The directors of a corporation owed a legal duty of care to the company they served and its shareholders. ${ }^{165}$ That duty, in turn, could be enforced in

161. It is unlikely Bullitt could have managed a constitutional challenge to the Act by means of an equitable suit against the Farm Loan Board, relying on a pre-APA nonstatutory form of administrative review. The shareholder suit Bullitt actually filed may best be understood as the kind of equitable action by which federal courts engaged in nonstatutory review at the time. $C f$. John F. Duffy, Administrative Common Law in Judicial Review, 77 Tex. L. Rev. 113, 146-49 (1998) (describing this murky body of judge-made remedial principles).

162. Federal Farm Loan Act, Pub. L. No. 64-158, § 4, 39 Stat. 360, 366 (1916).

163. Cf. Textile Workers Union v. Lincoln Mills, 353 U.S. 448, 450-51 (1957) (explaining the function of "sue and be sued" provisions).

164. $\$ 34,39$ Stat. at 388 .

165. See generally Bert S. Prunty Jr., The Shareholders' Derivative Suit: Notes on Its 
the courts via a shareholder derivative action against the directors and, in some instances, against third parties whose dealings with the company were allegedly unlawful. ${ }^{166}$ Charles Smith may seem to us to have been an unlikely candidate to mount a constitutional challenge to the 1916 Act and the tax-free bonds it authorized. But he was precisely the plaintiff Bullitt needed to achieve standing before an Article III court.

Shareholder actions were not always a sure thing. Indeed, the Supreme Court initially hesitated to permit them, especially when shareholder complaints spilled out of the company itself to reach other corporations or governmental regulators. The Court became more receptive as time went on. But the early precedents revealed a paradox. If shareholders and directors were actually in agreement and a shareholder suit was instituted only for litigation purposes, the Court usually went along. Illustrations include cases in which out-of-state shareholders lent their names to lawsuits to invoke federal diversity jurisdiction. ${ }^{167}$ If, however, shareholders were genuinely antagonistic to directors, the Court was reluctant to let them interfere with the directors' rightful control of company activities. ${ }^{168}$

In part, the Court reasoned that other companies transacted business with a corporation as an entity, without entering any relationship with individual shareholders, and that those other companies reasonably expected that if a deal excited litigation a suit would be advanced by the corporation with which they were in privity. More important for present purposes, the Court also worried that shareholder suits would undermine internal corporate governance and directors' ability to decide where a company's interests lay. In Hawes v. Oakland, accordingly, the Court held that, in the case of a suit "founded on a right of action existing in the corporation itself, and in which the corporation itself [was] the appropriate plaintiff," a shareholder had standing to sue only if the directors' behavior was fraudulent or "beyond the authority conferred on them by their charter." 169

\footnotetext{
Derivation, 32 N.Y.U. L. REV. 980, 988 (1957).

166. Id.

167. See infra text accompanying notes 202-05.

168. See Robert Charles Clark, Corporate Law 662-64 (1986). A derivative suit depended both on a breach of trust by the directors and on the company's status as an independent entity. In the absence of the former, a shareholder would have had no cognizable complaint about the directors' administration of the company's interests; in the absence of the latter, the shareholder would have had no corporate rights to champion against the third party. See Prunty, supra note 165, at $990-91,994$.

169. Hawes v. Oakland, 104 U.S. 450, 460 (1881). But see Ann Woolhandler, The Common
} 
The most recent precedent in point was the United Copper case, ${ }^{170}$ decided the year Bullitt started work. Justice Brandeis had written a cryptic opinion for the Court summarily rejecting an attempt by shareholders to sue other companies on United Copper's behalf. Brandeis explained that the action should have been dismissed, because the shareholders had not alleged that the defendant-companies' wrongful acts had caused injury to them as individuals, but only that the defendants' violations of federal law had damaged the corporation and that the directors had failed to file a suit for compensation. In the absence of exceptional circumstances, such as ultra vires conduct by the board, it was for the directors to decide whether to engage in litigation, not shareholders pressing a different agenda.

Bullitt must have seen Brandeis in particular as a threat. True, the issue in United Copper (as well as Hawes) had been whether shareholders could bring an action that was derivative in the sense that they purported to advance the company's rights against third partiessomething Bullitt had no intention (or ability) to do. Yet Brandeis had plainly signaled doubts about actions that were derivative in the baseline sense that shareholders purported to protect the company's rights against the directors. If Brandeis took the same attitude toward derivative suits in either flavor, Charles Smith might not have standing after all.

This risk explains the way Bullitt drafted the complaint in the Smith case-namely, to satisfy the concerns about derivative suits expressed in the Court's cases. He formally named the Trust Company itself as the sole defendant and explicitly asserted that the suit was "not founded on rights which [would] properly be asserted by the defendant Trust Company" against others. ${ }^{171}$ He thus expressly disclaimed any effort to represent the company against outsiders such as federal officials and bank managers. He alleged that the proposed purchase of the bonds was not authorized by the statutes governing the company's incorporation. And he alleged the very thing Brandeis had found missing from the complaint in United Copper-namely, that the shareholder himself would be "damaged in a large sum" if the planned bond purchases were not enjoined. ${ }^{172}$

\footnotetext{
Law Origins of Constitutionally Compelled Remedies, 107 YALE L.J. 77, 107-08 (1997) (explaining that federal courts sometimes allowed derivative suits when state courts would have declined).

170. United Copper Sec. Co. v. Amalgamated Copper Co., 244 U.S. 261 (1917).

171. Bill in Equity, supra note 138, at 10 (emphasis added).

172. Id. at 12. Cf. Thompson v. N. Am. Stainless, L.P., 131 S. Ct. 863, 869 (2011) (indicating that insofar as Article III is concerned a stockholder today can sue a company for firing an employee
} 
William Marshall Bullitt was nobody's fool. He would have understood that this complaint initiated a shareholder suit that would likely arouse objections from Justice Brandeis. It was derivative in the sense that the shareholder-plaintiff hoped to enforce the company's legal interests against the directors. Functionally, a suit against the company to keep it from purchasing bonds was also, necessarily, a suit against the directors to override their decision to do so. And a challenge to the directors' action was necessarily an attempt to spare the company, as well as shareholders, the injury that the purchase of invalid bonds would entail. The complaint explicitly alleged that the Trust Company, too, stood to suffer losses. ${ }^{173}$ Yet Bullitt undoubtedly hoped that by excluding federal officers and managers from the picture, he minimized the chance that Brandeis would balk, perhaps taking the full Court with him.

Consequences followed from this structure of the action in Smith. One, of course, was that the bill Bullitt filed articulated no claim for relief on the strength of a violation of federal law alone. ${ }^{174}$ The Trust Company could not be said to violate federal law simply by purchasing bonds. The only parties that might have been accused of acting unconstitutionally, the Farm Loan Board and the federally chartered banks, were not defendants. This seems anomalous, but there was no practical import. The beauty of the shareholder suit in Smith was that it supplied an effective vehicle for raising constitutional complaints about the conduct of federal officials and managers without making them defendants. If Bullitt thought it was important that the Federal Land Banks and Joint Stock Banks should be involved to make the test case serious, he could count on them to intervene. And they did.

The only claim the bill did advance was an alleged violation of state law-specifically that Missouri state statutes prohibited the Trust

in violation of federal law so long as the stockholder shows that "the value of his stock decreased as a consequence").

173. Bill in Equity, supra note 138, at 12. It would be dangerous to suggest that Bullitt meant to avoid the derivative model entirely by framing the suit as a "direct" shareholder action. The distinction between derivative suits on a corporation's behalf and direct actions advancing only shareholder interests has always been elusive. The suit in Smith would be treated as derivative today. See Tooley v. Donaldson, Lufkin \& Jenrette, Inc., 845 A.2d 1031, 1039 (Del. 2004) (explaining that in a "direct" suit, as opposed to a derivative action, "[t]he shareholder's injury must be independent of any alleged injury to the corporation") (emphasis added). But it is unimportant to this story to characterize the Smith action in one way or the other. It is only important to recognize that Bullitt drew the complaint as he did in an effort to respond to concerns about derivative actions, especially from Justice Brandeis.

174. See Bill in Equity, supra note 138. 
Company's purchase of tax-exempt farm bonds issued by federally chartered banks, albeit because both were allegedly unauthorized by the Federal Constitution. ${ }^{175}$ The bill asserted that provisions under which the Trust Company was organized provided that corporations could "buy, invest in and sell all kinds of government, state, municipal and other bonds and all kinds of negotiable and non-negotiable paper, stocks or other investment securities."176 Bullitt contended that the clear implication was that the company was authorized to make only "real legal 'investments,' as distinguished from those which [were] unauthorized and pretended." 177 That argument was contestable. But here, too, there were no practical implications. All the defendants expressly conceded that Bullitt interpreted the Missouri statutes correctly and that, if the bonds lacked federal constitutional foundation, the company's purchase of them would violate its charter as a matter of state law. ${ }^{178}$

Finally, the state-law basis of the action in Smith invited Justice Holmes's objection that the district court lacked subject matter jurisdiction. There was some irony in this. It is entirely possible that the masterful lawyer representing the plaintiff in Smith carefully and skillfully named the Trust Company as the defendant and alleged only a violation of state law as a hedge against the position on shareholder suits he anticipated from Justice Brandeis, only to find that Brandeis would not sit on the Smith case. Then, by grounding the complaint in state law to satisfy Brandeis, he ran headlong into Holmes's position on federalquestion jurisdiction. But that did not matter either, because a strong majority of the Justices rejected Holmes's view of the jurisdictional issue. $^{179}$

A shareholder suit was crucial for purposes of standing to challenge the Farm Loan Act, given that Bullitt's actual clients, competing private banks, lacked the necessary legal interest. Still, it is possible that Bullitt's painstaking efforts to frame a shareholder action that would negotiate precedents like Hawes and United Copper were unnecessary in the end. The defendants raised no objections, and the district court ignored the procedural posture of the case. In the Supreme Court, Brandeis recused

\footnotetext{
175. Id. at 7 .

176. Id

177. Appellant's Revised Brief, supra note 26, at 3.

178. Id. at 4 (reporting that opposing counsel conceded the propriety of the shareholder action founded on the theory that the Trust Company's purchase of bonds would violate its state charter).

179. Smith v. K.C. Title \& Trust Co., 255 U.S. 180, 215 (1921).
} 
himself ${ }^{180}$ and the rest of the justices expressed no reservations about the shareholder nature of the suit. Justice Day's opinion made nothing of the specifics in the bill, saying only that the "general allegations as to the interest of the shareholder" were sufficient. ${ }^{181}$

\section{Equity Jurisdiction}

The Smith case was initiated before the merger of law and equity. Looking back now, it is difficult always to isolate discussions of equity jurisdiction in a district court from discussions of standing. The Supreme Court described the question in Hawes, for example, as whether the plaintiff in that case had "standing in a court of equity." 182 Yet since Bullitt's purpose was to secure a federal injunction, he necessarily had to satisfy the familiar prerequisites for proceeding on the equity side of the district court.

Here, too, a shareholder suit supplied an answer. A shareholder action was itself a creature of equity, originally developed by Chancery to fill the gap when the law courts refused to settle intra-corporate disputes. ${ }^{183}$ When Bullitt took up his task in Smith, he had the benefit of earlier cases in which shareholder suits had proven their value to corporations pursuing equitable relief.

The great income tax cases, Pollock ${ }^{184}$ and Brushaber, ${ }^{185}$ are illustrations. The corporations in those cases could not themselves sue federal tax collectors for judicial protection up front, but had to pay objectionable taxes and ask for a refund later. In classic language, a corporation had an adequate remedy at law in the form of a suit for reimbursement. Applicable statutes adopted the same policy. Specifically, § 3224 of the Revised Judicial Code barred a federal court from entertaining a suit "for the purpose of restraining the assessment or collection of any tax."186 In Pollock and Brushaber, however, the Court

\footnotetext{
180. Id. at 213.

181. Id. at 202 .

182. Hawes v. Oakland, 104 U.S. 450, 462 (1881).

183. See Prunty, supra note 165, at 980-85. The shareholders in United Copper sought damages for violations of the Sherman Act. Justice Brandeis explained that if the shareholders could enforce their corporation's rights at all, it was only in pursuit of an equitable remedy. United Copper Sec. Co. v. Amalgamated Copper Co., 244 U.S. 261, 265 (1917).

184. Pollock v. Farmers' Loan \& Trust Co., 157 U.S. 429 (1895).

185. Brushaber v. Union Pacific Co., 240 U.S. 1 (1916).

186. Rev. Stat. § 5947, 3 U.S. COMP. STAT. 1913, p. 2638. Neither the equitable rule nor its statutory analog withheld judicial power. See Sunshine Anthracite Coal Co. v. Adkins, 310 U.S. 381 (1940) (entertaining a suit by a company to enjoin the collection of a tax without mentioning this
} 
held that a shareholder suit to keep a corporation from paying taxes was not the same as a suit by the corporation resisting payment. So a shareholder could invoke a federal court's equitable jurisdiction to enjoin the payment of taxes by the corporation, $\S 3224$ notwithstanding.

In Smith, Bullitt had no need to get around the special limits on equity jurisdiction captured in $\S 3224$. He was making no attempt to enjoin the collection of taxes, only to prevent the Trust Company from trying to take advantage of tax exemptions. ${ }^{187} \mathrm{He}$ had only to satisfy the familiar requirements for a shareholder action to protect the company from the board of directors. The elements of such a suit comprised a context-specific facsimile of the traditional conditions for equity jurisdiction-conditions ensuring that the plaintiff acted in good faith and faced irreparable harm that only an injunction could forestall. In a derivative action, the shareholder had to allege not only that the directors were acting or threatening to act ultra vires, but also that the shareholder had "exhausted all the means within his reach to obtain, within the corporation itself, the redress of his grievances." 188 Bullitt had no difficulty with this, explaining in the complaint that Charles Smith had objected to the purchase of the bonds, that the board had held a meeting on the question, and that the directors had adopted a formal resolution declaring their position that the bonds were valid and their intention to go ahead with the deal. ${ }^{189}$

In this instance, too, Bullitt's careful lawyering was probably unnecessary. The defense objected that the allegations in the bill failed to state a "cause of action in equity." 190 But we will see in a moment that the idea was to join issue on the constitutional questions. ${ }^{191}$ The district court dismissed the bill "for want of equity." 192 But there, too, the clear meaning was that the plaintiff's constitutional claims were rejected on the merits. ${ }^{193}$ In the Supreme Court, Justice Day cited the directors' declaration that they meant to purchase farm bonds and referred to Smith

\footnotetext{
issue); see also Helvering v. Davis, 301 U.S. 619, 639-40 (1937) (allowing the government to waive a defense under $\S 3224)$.

187. Smith v. K.C. Title \& Trust Co., 255 U.S. 180, 215 (1921).

188. Hawes v. Oakland, 104 U.S. 450, 460-61 (1881). Cf. FED. R. CIV. P. 23.1 (listing essentially these same requirements for derivative shareholder actions today).

189. Bill in Equity, supra note 138, at 10.

190. Motion to Dismiss, Smith v. K.C. Title \& Trust Co. (W.D. Mo. Oct. 22, 1919) (No. 212).

191. See infra text accompanying notes 210-13.

192. Transcript of Record at 30, Smith v. K.C. Title \& Trust Co., 255 U.S. 180 (1921).

193. See infra text accompanying notes 226-27.
} 
as an "objecting shareholder." 194 But he dealt with the district court's jurisdiction in equity only by announcing the conclusion that the allegations in the bill "[gave] jurisdiction" under Pollock and Brushaber. ${ }^{195}$

\section{Jurisdiction of the Subject Matter}

The third threshold question in Smith was the one that ultimately divided the Supreme Court-namely, the district court's subject matter jurisdiction. ${ }^{196}$ Today, a competing company with standing to sue typically can establish federal-question jurisdiction for a constitutional attack on a statute like the Farm Loan Act. The statute itself might contain a provision conferring federal jurisdiction in specified cases likely to arise. In the absence of a special jurisdictional grant, the general federal-question jurisdictional statute, 28 U.S.C. § 1331, almost always answers. ${ }^{197}$ But, here again, the options open to Bullitt were more limited.

There was no jurisdiction-conferring provision in the 1916 Act. ${ }^{198}$ Nor was the "sue and be sued" clause up to the task. In the Osborn case, ${ }^{199}$ John Marshall had construed a similar clause to confer jurisdiction on federal courts in cases affecting the Second National Bank. Marshall rationalized Osborn's jurisdictional holding on the ground that the "sue and be sued" clause in that case explicitly referred to suits in federal court. ${ }^{200}$ The clause in the Farm Loan Act was more general, referring to "any court of law or equity."201

\footnotetext{
194. Smith v. K.C. Title \& Trust Co., 255 U.S. 180, 201 (1921).

195. Id. at 202 .

196. At the time, lawyers and judges tended to say (and perhaps to think) that a plaintiff's ability to proceed in equity went to the court's authority to entertain an action. Yet, even then, subject matter jurisdiction, properly understood, presented a separate question. See Mass. State Grange v. Benton, 272 U.S. 525, 528 (1926) (acknowledging the way professionals talked about equity but explaining that a federal court's power to adjudicate was not implicated).

197. See Mims v. Arrow Fin. Servs., LLC, 132 S. Ct. 740, 749 (2012) (recognizing a presumption in favor of $\S 1331$ jurisdiction).

198. There is a little legislative history indicating that federal jurisdiction was assumed. Representative Cullop offered a floor amendment that would have acknowledged state court jurisdiction "in all proceedings instituted under the provisions of this act." 53 CONG. REC. 8004-05 (1916). Cullop contended that, in the absence of an explicit provision on state court authority, federal officials (presumably he meant officials of federally chartered banks) would always bring foreclosure actions in federal court. His amendment was defeated without serious debate. Id.

199. Osborn v. Bank of United States, 22 U.S. (9 Wheat.) 738 (1824).

200. Id. at 817-18. See also Am. Nat'1 Red Cross v. S.G., 505 U.S. 247, $253-54$ (1992).

201. Federal Farm Loan Act, Pub. L. No. 64-158, § 4, 39 Stat. 360, 363 (1916).
} 
A shareholder suit once more provided Bullitt with what he needed. Corporate lawyers before him had used shareholder derivative actions to manufacture diversity jurisdiction for litigating federal constitutional claims. If a corporation had a dispute with another local party and wanted to sue in federal court, the corporation declined itself to take legal action but still managed the trick by recruiting an out-of-state stockholder as a surrogate. In Dodge v. Woolsey, ${ }^{202}$ for example, a citizen of Connecticut who owned stock in a Cleveland bank (Woolsey) contended that the bank directors were set to comply with an effort by an Ohio tax collector (Dodge) to enforce an Ohio law subjecting the bank to a tax, the imposition of which would violate the Contract Clause. Woolsey had written to the directors to demand that they resist the tax. The directors had responded that, while they agreed that the tax was unconstitutional, they would not file their own action due to undisclosed "obstacles in the way of testing the law in the courts of the State." 203 Dodge objected that the suit was collusive. Yet he offered no proof, and the Supreme Court confirmed the circuit court's jurisdiction.

The Justices were awake to the potential of shareholder suits to create federal diversity jurisdiction routinely. In Hawes $v$. Oakland, the Court recognized that the number of shareholder diversity actions had increased significantly after Dodge. ${ }^{204}$ Yet if the claims advanced were federal, the Court was content that diversity jurisdiction could be invoked to get them into federal court. ${ }^{205}$ If the Justices had it in mind to put a stop to the practice, they changed their minds when Congress enacted the Judiciary Act of 1875 , which contained the forerunner to $\S$ 24 - conferring original trial-level federal jurisdiction in suits "arising under" federal law. ${ }^{206}$ That change eliminated the incentive to invoke diversity jurisdiction at all in cases that could be heard under the new provision for federal-question jurisdiction. In Hawes, the Court said that a suit like the one in Dodge would "undoubtedly" now come within a district court's jurisdiction by virtue of the federal constitutional claim alone. $^{207}$

\footnotetext{
202. 59 U.S. (18 How.) 331 (1855).

203. Id. at 340 .

204. Hawes v. Oakland, 104 U.S. 450, 452 (1881). See supra text accompanying note 169. The income tax cases, Pollock and Brushaber, were also diversity actions.

205. Woolhandler, supra note 169, at 92-98 (contending that the Court approved of diversity actions generating jurisdiction for constitutional arguments).

206. Jurisdiction and Removal Act of 1875, ch. 137, § 1, 18 Stat. 470 (1875).

207. Hawes, 104 U.S. at 459.
} 
With cases like Dodge and Hawes on the books, Bullitt had a choice. He could concoct diversity jurisdiction easily enough, so long as he was careful about it and deflected a provable charge of collusion. It is hard to think he could not identify an out-of-state shareholder to substitute for Charles Smith. If all the stock in the Trust Company was held locally, he might have shifted to a different corporation. The Trust Company was scarcely the only firm around. Any corporation anywhere in the country would serve as well (for these purposes) if it invested in farm loan bonds. Moreover, by invoking diversity Bullitt could avoid the well-pleaded complaint rule, which restricted jurisdiction under $\S 24$ to cases in which a federal question appeared in a properly pleaded complaint. ${ }^{208}$

Then again, Bullitt could also invoke federal-question jurisdiction. There was no real doubt that his bill in equity would refer to a federal issue. To plead that the company was about to violate state law, the bill would have to allege that there was something unlawful about purchasing the bonds. And to allege that, the bill would properly identify the constitutional flaws Bullitt saw in them. Of course, the Court had already indicated in Hawes that federal-question jurisdiction was available where the issues to be decided were constitutional. ${ }^{209}$ In the event, Bullitt invoked district court jurisdiction exclusively under $\S 24$. Since the case implicated the validity of a federal statute, it arose "under the Constitution and laws of the United States." 210

Not only did a shareholder suit generate subject matter jurisdiction. It provided an opportunity to collect in one action any and all constitutional complaints about the Farm Loan Act. Every constitutional charge that could plausibly be advanced was presented inasmuch as all the arguments went to the validity of the bonds the Trust Company was about to buy, thus to the dispute between the shareholder and the directors over the lawfulness of the proposed purchase. Nothing could have been neater.

No one on the defense side objected to the district court's subject matter jurisdiction, and the district court raised no doubts of its own. The Supreme Court's treatment of the question is examined below in Part IV. Suffice it to say here that, for good reason, the parties plainly perceived no difficulty with federal-question jurisdiction when the gravamen of the dispute was the constitutionality of a federal statute.

\footnotetext{
208. Louisville \& Nashville R.R. Co. v. Mottley, 211 U.S. 149, 153 (1908).

209. 104 U.S. at 459.

210. Bill in Equity, supra note 138, at 2.
} 
The full Court, through Justice Day, acknowledged the issue but was easily convinced for the same reason. Justice Holmes was not, of course, and we will come to his thinking in Part IV.

$$
* * *
$$

Bullitt was hired by private mortgage lenders vexed by competition from federally chartered banks that could raise capital cheaply by issuing tax-exempt bonds. As he sized up the situation, he decided that the hurdles in the way of a successful constitutional challenge to the 1916 Act and the tax exemptions for farm bonds could best be cleared by pressing a shareholder's allegation that his own company was threatening to make unlawful bond purchases. For standing, Bullitt could rest on the shareholder's ability to charge that the directors' acquisition of bonds would violate their legal obligations to the company and its shareholders. For jurisdiction in equity, he could plead the traditional conditions for a shareholder derivative action. For subject matter jurisdiction, he could rely on the federal-question jurisdictional statute as it had already been interpreted (at least in dictum). Small wonder Bullitt filed the shareholder suit he did. Given what he knew or reasonably anticipated, he could scarcely have done anything else.

\section{The District Court}

Counsel to the Trust Company, Justin Bowersock, made but one contribution in the trial court - a motion to dismiss "for the reason that the bill of complaint, as amended, [did] not state facts sufficient to constitute a cause of action in equity." 211 At a glance, one might understand that Bowersock at least meant to contest jurisdiction on the equity side of the court. But he charged no collusion and acquiesced in the allegations setting up the shareholder action - that is, the assertion that Smith had asked the directors to desist and had been refused. So it appears that he meant only to say that the allegations in the complaint, if proven to be true, would not establish that the Act and the tax exemptions were unconstitutional such that an injunction should issue. In the Supreme Court, Justice Day described Bowersock's motion as effectively a demurrer, although that pleading instrument had been abolished by the Equity Rules in $1912 .^{212}$ Now, we would call it a Rule

211. Motion to Dismiss, supra note 190.

212. Smith v. K.C. Title \& Trust Co., 255 U.S. 180, 198 (1921). 
12(b)(6) motion to dismiss the bill for failure to state a claim for which relief could be granted - a contention that goes to the merits. ${ }^{213}$ As to the merits, moreover, recall that Bowersock agreed that the purchase of farm bonds would violate state law. ${ }^{214}$ In that way, too, he plainly showed that he had no desire to box the case out of court. He wanted to engage and defeat Bullitt's constitutional claims.

The heavy lifting on the defense side was done by counsel for the intervenor federal banks. Since Charles Evans Hughes had already produced a favorable legal opinion on the validity of the Act, it is no surprise that the Farm Loan Board retained him to represent the Land Banks. ${ }^{215}$ Nor is it surprising (really) that George Wickersham and William McAdoo appeared for the Joint Stock Banks and McAdoo for the United States as amicus. Both had just left the Administration, and McAdoo had been vitally involved in drafting the Act and starting the new scheme in motion. ${ }^{216}$ The attorneys for the defense focused exclusively on the constitutional challenge - to the extent that they made suggestions for brushing up the original complaint to "more fully present the case" against their own position. ${ }^{217}$

The district judge, Arba S. Van Valkenburgh, was also a man of parts. He had been appointed by President Taft after gaining fame as the prosecutor in major suits to enforce the Elkins Act (which protected railroads from demands for rebates). His work in Smith was perfunctory, but for good reason. Van Valkenburgh understood perfectly well that the parties planned to take this test case to the Supreme Court and frankly said as much at the end of the proceedings. He compared a trial court in a case of this kind to a railway platform. The court's decision was "not for the purpose of standing upon, but for the purpose of getting into the Supreme Court." ${ }^{218}$

Van Valkenburgh scheduled an early hearing on Bowersock's

213. Fed. Dep’t Stores v. Moitie, 452 U.S. 394, 399 (1981).

214. See supra note 178 and accompanying text.

215. See The Autobiographical Notes of Charles Evans Hughes 192-93 (David J. Danelski \& Joseph S. Tulchin eds., 1973) [hereinafter AUTOBIOGRAPHICAL NoTES] (explaining that Hughes was retained in Smith as a result of the "elaborate opinion" he had given to the bond houses).

216. McAdoo to Aid Palmer, N.Y. TimES, Sept. 9, 1919, at 14 (reporting that McAdoo accepted only one dollar for his services).

217. Appellant's Revised Brief, supra note 26, at 5. The only surviving evidence of this is a representation by Bullitt, offered in service of his efforts to persuade the Supreme Court to reach the constitutional issues. Id. at 5 (explaining that "[t]he bill so as to more fully present the case, was, at the suggestion of the Government and these banks, in certain unnecessary respects, amended ... by interlineation").

218. Transcript of Record at 22, Smith v. K.C. Title \& Trust Co., 255 U.S. 180 (1921). 
motion. The primary facts were not in dispute; the constitutional questions could hardly have been more hotly contested. Bowersock opened with a statement of the issues; McAdoo followed with a description of the Act and its operative features; then Hughes, Wickersham, and McAdoo engaged with Bullitt over the points Hughes had made in his opinion for the bond houses.

In reply to Hughes's contention that the Act could rest on Congress's powers to tax, spend, and borrow, Bullitt insisted that Land Banks were not primarily mechanisms by which the government disposed of its own treasure for the general welfare or managed its own finances. $\mathrm{He}$ contended Land Banks were private entities that generated funds from private sources, operated for the benefit of farmers and investors, and served no genuine public purpose. Joint Stock Banks, which received no government funds, were even less defensible. ${ }^{219}$ Hughes himself acknowledged that Joint Stock Banks might be in a different category and noted that their status raised a "separable" issue. ${ }^{220}$

For their part, Wickersham and McAdoo denied any signal difference between Land Banks and Joint Stock Banks for constitutional purposes. True, Congress's powers to tax, spend, and borrow were less in evidence in the case of Joint Stock Banks. Yet Wickersham and McAdoo maintained that the public functions they performed (or, at least, could perform) were not eclipsed by their largely private character and activities. ${ }^{221}$ Joint Stock Banks shared numerous features with Land Banks, not the least of which was the pervasive supervision the Farm Loan Board exercised with respect to both. ${ }^{222}$

Speaking for the government, McAdoo endorsed the arguments in the other briefs and added two more. He contended that the Land Banks and Joint Stock Banks were indistinguishable constitutionally from ordinary national banks, which had existed for a half-century and whose

219. A stenographer took notes at the hearing, but no official transcript was made. $C f$. Letter from Charles E. Hughes to William M. Bullitt (Nov. 6, 1919) (on file with Filson Historical Society) (complaining that "at times it [was] apparent that the stenographer was lost and failed to catch what [Hughes] said"). The account in the text is based on Bullitt's summary of the contending positions in a speech to the Kansas Bankers Association, reprinted in 12 LAW. \& BANKER 777, 780 (1919), and on the parties' briefs in the Supreme Court.

220. Brief for Appellee, Federal Land Bank of Wichita, Kansas, at 1, Smith v. K.C. Title \& Trust Co., 255 U.S. 180 (1921) (No. 199) (brief on reargument). The brief was actually signed by W.W. Willoughby, of counsel. Id. at 14.

221. Brief for the United States as Amicus Curiae at 28-29, Smith v. K.C. Title \& Trust Co., 255 U.S. 180 (1921) (No. 199).

222. Id. at $29-30$. 
constitutional footing had long since been sustained. ${ }^{223}$ And he argued that the Farm Loan Act could rest on an alternative ground: Congress's authority to declare and make war. ${ }^{224}$ The United States had not yet formally entered hostilities when the Act was adopted. But, by McAdoo's account, the country was preparing for the dislocations the war would entail-which included potential disruptions in the food supply. ${ }^{225}$

At the end of the second day, Judge Van Valkenburgh dealt with the constitutional arguments from the bench. He had "no question" regarding the validity of the Land Banks "in any respect." $226 \mathrm{He}$ acknowledged that the Joint Stock Banks were arguably distinguishable. Yet they, too, might be made financial agents of the government and depositaries of its funds. If they were to be struck out of the Act, the Supreme Court itself would have to make the decision. Then and there, Van Valkenburgh declared both the Land Banks and the Joint Stock Banks constitutionally valid and informed the parties that the bill would be "dismissed for want of equity." 227

\section{The Supreme Court}

With Judge Van Valkenburgh's decision in place, the parties were anxious to get on with the appeal-which by statute went directly to the Supreme Court. ${ }^{228}$ Bullitt filed a motion to advance the case on the Supreme Court's docket, and all the defendants' attorneys signed it. Their reasoning was plain. The crucial issue was the constitutionality of tax exemptions for farm loan bonds; bonds said to be worth hundreds of millions of dollars were on the table; banks, investors, and borrowers were in turmoil while any uncertainty continued. The validity of the tax exemptions depended, in turn, on the constitutionality of the 1916 Act itself, and the district court order cleanly presented that question. ${ }^{229}$ The Court at first obliged. The appeal was docketed in November and scheduled for argument two months later.

223. Id. at 25-26 (citing Farmer's \& Mechanics' Nat'l Bank v. Dearing, 91 U.S. 29 (1875), and First Nat'l Bank of Bay City v. Fellows ex rel. Union Trust Co., 244 U.S. 416 (1917)).

224. Id. at 54. See U.S. Const. art. I, § 8, cl. 11-16.

225. Id. at 56.

226. Transcript of Record at 24, Smith v. K.C. Title \& Trust Co., 255 U.S. 180 (1921).

227. Id. at 30 .

228. See supra note 3 and accompanying text.

229. Appellant's Motion to Advance, Nov. 8, 1919, Smith v. K.C. Title \& Trust Co., 255 U.S. 180 (1921) (No. 199). 
In 1920, the Supreme Court heard arguments in the Old Senate Chamber, an elegant, semicircular room in the Capitol building with a thick brown carpet, velvet-cushioned seating, and marble busts of former Chief Justices along the wall behind the raised bench at which the Justices were seated. ${ }^{230}$ On this occasion, one chair was vacant. Justice Brandeis would not participate. There is no surviving (reliable) explanation. The personal relationship between Brandeis and Hughes could not have been the cause. The two were old friends; many years earlier, their law firms had worked on cases together. ${ }^{231}$ But Hughes obviously knew most of the Justices from his own days on the Court. And he appeared in other cases that prompted no recusals -including one decided on the same day that Smith came down. ${ }^{232}$ By one account, Brandeis recused himself because he personally held farm loan bonds. ${ }^{233}$

The argument consumed three days. The lawyers and Justices fastened their attention on the constitutional issues. ${ }^{234}$ At one point, Justice McReynolds interrupted to ask whether it was all so clear that the case was properly before the Court. ${ }^{235}$ Apart from that, there appeared to be no reason why the Justices would not render a quick decision on the merits. It did not happen. Three months passed, and on the last day of the Term the Court restored the case to the docket and ordered reargument the following year.

The lawyers were perplexed. They had labored to obtain a decision on the constitutional questions as soon as possible. The Court had seemed willing, but now there was evidently some snag. No reason was given for the postponement, and there is no surviving evidence of what the Justices were thinking. Wickersham later speculated that they wanted more time to consider subject matter jurisdiction. ${ }^{236}$ But the parties were not asked for briefing on that point - and they, in fact, provided none. They dutifully asked that the reargument at least should

\footnotetext{
230. BERnARD SCHWARTZ, History OF THE SUPREME COURT 101 (1993).

231. See AutobiographiCAL Notes, supra note 215, at 298.

232. Detroit United Ry. v. City of Detroit, 255 U.S. 171 (1921). Justice Day wrote for a unanimous Court. Hughes's side lost.

233. Preston, supra note 63, at 438 n.1 (citing no evidence).

234. No transcript of the argument has survived.

235. The only evidence of McReynolds's question is in the Appellant's Revised Brief, supra note 26 , at 29.

236. Letter from George W. Wickersham to William M. Bullitt (March 3, 1921) (on file with Filson Historical Society) (speculating, but not purporting to know, that the "delay in reaching a result concerned the jurisdictional point more than the substance of the contention").
} 
be expedited. ${ }^{237}$ And they prepared revised briefs that amounted to a reprise of their positions on the merits.

Only Bullitt touched on the "propriety" of the case "to test the grave constitutional questions." 238 He made no real argument, but only directed the Court's attention to Brushaber and offered "remarks" that "while probably unnecessary" were "prompted by" the "passing inquiry" from McReynolds at oral argument. ${ }^{239}$ Bullitt said only that the "propriety of the proceedings" had never been contested below and all the lawyers now wanted the Court to determine "the validity of the legislation." 240 This was not to contend that subject matter jurisdiction existed because the parties had consented. No one would have proposed that. The citation to Brushaber suggests that Bullitt had in mind federal equity jurisdiction - a matter that the defense could waive. Probably, Bullitt only meant to whistle past any jurisdictional graveyard and to discourage the Justices from ducking the constitutional questions. It was late, everybody was tired, and no one wanted to go home without a resolution of the issues all had come to Washington to resolve. The Court took two more days of argument the following October-with no (recorded) special attention to jurisdiction. Then, in February of 1921, Justice Day delivered the Court's decision.

William Rufus Day was a Republican from Ohio, born to a family of lawyers and judges. His father had been Chief Justice of the Ohio Supreme Court. Day himself had a general practice in Canton, where he befriended and advised William McKinley, who later named Day Secretary of State in the middle of the Spanish-American War. When Theodore Roosevelt failed to persuade William Howard Taft to take a position on the Supreme Court in 1903, he named Day as an acceptable Ohio alternative. ${ }^{241}$ On the Court, Justice Day had a deserved reputation for conservative views regarding congressional power; he generally insisted that the Commerce Clause authorized only the regulation of transportation. ${ }^{242}$ Yet he was not among the Court's most doctrinaire defenders of corporate practices; he generally approved vigorous

237. Appellant's Motion to Advance at 2, Smith v. K.C. Title \& Trust Co., 255 U.S. 180 (1921) (No. 199).

238. Appellant's Revised Brief, supra note 26, at 28.

239. Id. at 28-29.

240. Id.

241. Joseph E. McLean, WiLliam Rufus Day: Supreme Court Justice From OHIO 14-15, $19,30,51,54-56$ (1946).

242. See, e.g., Edward S. CORwIN, The Twilight OF THE SUPREME COURT 26-27 (1934). 
enforcement of the antitrust laws. ${ }^{243}$ An admiring biographer contends that Day was a voice of moderation. He "instructively grasped ... the importance of the ever-increasing concentration of corporate power."244

Justice Day first satisfied himself regarding subject matter jurisdiction before going on to the merits. In light of the precedents then in place, it is hardly surprising that he confirmed the district court's jurisdiction and, in turn, the Supreme Court's own jurisdiction on direct review - bracketing for the moment Justice Holmes's position in dissent. On the basic question whether $\S 24$ conferred jurisdiction on the district court, Day might simply have adopted the dictum in Hawes. ${ }^{245}$ Day invoked the "general rule" that $\S 24$ jurisdiction was sustained if the plaintiff's "right to relief" depended on "the construction or application of the Constitution" - provided the claim was "not merely colorable" and rested on a "reasonable foundation." $246 \mathrm{He}$ cited nothing for that rule, apart from similar language in Osborn, where (Day conceded) the Court had described the outer boundaries of federal-question jurisdiction within the meaning of Article III- this is to say, the jurisdiction Congress had constitutional power to confer on federal courts rather than the jurisdiction Congress had actually granted.

Beyond Osborn, Day relied on the income tax cases, Pollock and Brushaber, albeit he acknowledged that both had been diversity actions. Those decisions, he explained, established two points. The first was immaterial in Smith. Day recalled that Pollock and Brushaber had held that $\S 3224$ posed no bar to a shareholder invoking federal equity jurisdiction to enjoin a corporation from paying an allegedly unconstitutional tax. ${ }^{247}$ Fair enough. But then the shareholder in Smith was not trying to keep the Trust Company from paying taxes, only from buying bonds on the promise they were tax free.

Second, Day recalled that, in Brushaber, the Court had reviewed a district court judgment directly pursuant to $\S 238$, leapfrogging over the relevant circuit court of appeals on the theory that the validity of a federal statute was drawn in question. This point was pertinent, given that the shareholder in Smith also invoked $\S 238$ to obtain immediate Supreme Court review. Still, the (noncontroversial) proposition in Brushaber that $\S 238$ secured appellate jurisdiction for the Supreme

243. MCLEAN, supra note 241, at 82-83.

244. Id. at 113 .

245. See supra text accompanying note 207.

246. Smith v. K.C. Title \& Trust Co., 255 U.S. 180, 199 (1921).

247. See supra text accompanying notes $184-86$. 
Court (ceteris paribus) proved nothing about the district court's original jurisdiction below. If the district court in Smith had acted without original jurisdiction under $\S 24$, no one would have thought that $\S 238$ could bootstrap appellate jurisdiction in the Supreme Court simply because the case involved the constitutionality of a federal statute. In his dissent, Holmes said only that he saw nothing in Brushaber that was "contrary to" his views and that his own objection to the district court's jurisdiction in Smith had not been "before the mind of the Court [in Brushaber] or the subject of any of its observations."248

Turning to the merits, Justice Day bypassed Hughes's primary argument that Congress could create the new federal scheme for rural credit under its power to tax and spend for the general welfare. $\mathrm{He}$ focused, instead, on Hughes's second contention, also grounded in McCulloch v. Maryland, that Congress could establish public institutions, including these new banks, as instruments for handling the federal government's financial affairs. In this, Day seized upon the provisions that Congress had placed in the Act for the sole purpose of giving him something to seize upon-namely, the provisions giving Treasury authority to designate the banks as financial agents of the United States and depositaries of government funds. ${ }^{249}$ Day took what Congress gave him despite the certain knowledge that it had precious little to do with the basic thrust of the program the Act brought into being. It was beside the point that Treasury had never exercised the authority to employ Federal Land Banks and Joint Stock Banks in aid of the government's own financial operations. It was sufficient that the authority existed. ${ }^{250}$

On the surface, this was surprising. John Marshall had declared in McCulloch that Congress could not rest legislation on a pretext. ${ }^{251}$ Day himself had written the Court's notorious opinion in the Child Labor Case, invalidating a prohibition on the interstate shipment of goods manufactured with child labor on the ground that the true purpose was to discourage the exploitation of children. ${ }^{252}$ But more recently, in United

\footnotetext{
248. Smith, 255 U.S. at 215 (Holmes, J., dissenting).

249. See supra text accompanying notes 71-73.

250. Smith, 255 U.S. at 210. Hughes recalled Day's opinion this way in famous lectures delivered at Columbia in 1927. Charles Evans Hughes, THE Supreme Court OF THE United STATES 102 (1927).

251. McCulloch v. Maryland, 17 U.S. 316, 423 (1819).

252. Hammer v. Dagenhart, 247 U.S. 251, 276 (1918).
} 
States v. Doremus, ${ }^{253}$ Day had said that if legislation enacted by Congress had a "reasonable relation" to the taxing authority, it could not be struck down "because of the supposed motives which induced it." 254 It was clear enough in Smith that Congress had created federally chartered banks to make loans to farmers, but here, too, the true purpose of congressional action was immaterial.

One may say that Day took the path of least resistance in Smith and avoided the more expansive argument that Congress could do precisely what everyone understood the Act was meant to do-that is, charter federal institutions to make low-interest loans to farmers for the sole reason that Congress thought the general welfare would be served. Yet there is a way Day's approach held the potential for even more sweeping congressional power. He disclaimed any authority in the Court to curb legislative policy-making by holding Congress within formal categories the Justices themselves ascribe to the document: "With the wisdom and policy of this legislation we have nothing to do." "255 If Congress inserted something in a statute that supplied a link to a settled power, Congress was free to leverage that link to achieve much more ambitious goals.

$$
* * *
$$

The constitutionality of the 1916 Act was now settled. Next day, the Farm Loan Board announced that it would immediately authorize the issuance of all the bonds that had already been approved but had been held up while the Smith case was pending. ${ }^{256}$

\section{SUBJECT MATTER JURISDICTION REVISITED}

Since it was so plain to the lawyers that the district court's jurisdiction could rest on $\S 24$, and since Justice Day's opinion for the Supreme Court confirmed that understanding, one may wonder why the jurisdictional issue in Smith still attracts attention. The explanation is that Day's reasoning is thought to clash with the modern Court's treatment of federal-question jurisdiction under $\S 1331$. The Court now rationalizes the result Day reached, but embraces what it understands Justice Holmes to have meant as the baseline rule from which Day (in




hindsight) justifiably departed. According to the Court, Holmes articulated the right general approach, but reached the wrong conclusion in the case at hand.

The Court has it that, in general, a civil action "arises" under federal law for purposes of $\S 1331$ only if the plaintiff's authority to sue is federal. The law that must be federal is the law that provides the plaintiff's vehicle for seeking judicial relief. The Court is convinced that this interpretation of $\$ 1331$ works well enough most of the time, though it has some odd implications. ${ }^{257}$ Moreover, the Court insists this understanding has solid support in precedents stretching back to Holmes, who initially declared in Well Works, and repeated in Smith, that a suit "arises under the law that creates the cause of action."258 By the Court's account, a "cause of action" is not a litigant's substantive claim (the alleged violation of law with which the plaintiff charges the defendant), but the authority bestowed on the litigant to press a claim in court (the litigant's entitlement to ask for a judicial remedy). ${ }^{259}$

This focus on the source of a litigant's ability to pursue judicial relief can be explained as a matter of policy or, if you like, as a reflection of the Court's view that it is for Congress to make the policy decision whether jurisdiction should be conferred on federal courts. The text of $\S$ 1331 invites the interpretation that any case implicating a federal issue is within a district court's power to hear. But the Court hesitates to say that Congress has opened the district courts' doors so widely. So the Justices demand a better basis for concluding that Congress genuinely wants to grant federal courts original jurisdiction to adjudicate private suits in a particular context - a better basis, this is to say, than the bare language of $\S 1331$. Firmer ground is generally supplied by Congress's authorization of private suits. If Congress enables private actions, the Court takes Congress to contemplate that district courts will have subject matter jurisdiction to entertain them.

If Congress fails to authorize private litigation, the Court as a rule

257. For example, if a plaintiff sues a state officer for violating the Fourteenth Amendment, a district court has $\S 1331$ jurisdiction to entertain the action - not because the Fourteenth Amendment is in the Constitution, but because the statute that probably authorizes the suit, 42 U.S.C. $\S 1983$, is in the United States Code.

258. Am. Well Works Co. v. Layne \& Bowler Co., 241 U.S. 257, 260 (1916); Smith, 255 U.S. at 215 (Holmes, J., dissenting).

259. Herein the host of recent cases on the (nonjurisdictional) question whether Congress has provided for private lawsuits to enforce various federal statutes. The Court frequently substitutes the phrase "right of action," which goes some way toward defusing the confusion sown by the "cause of action" formulation. 
infers that Congress does not want $\S 1331$ jurisdiction to exist. That inference is defeated, however, if other circumstances indicate that $\S$ 1331 jurisdiction is warranted and within Congress's contemplation, despite the absence of a private "cause of action" that would seal the deal alone. The Court spelled those circumstances out in Grable. ${ }^{260}$ Jurisdiction can rest on $\S 1331$ even though the plaintiff's authority to sue is supplied by state law-(1) if the suit raises a non-frivolous question of federal law; (2) if the federal issue is actually contested and "substantial" in the sense that it entails a "serious interest" in "the experience, solicitude, and hope of uniformity that a federal forum offers;" and (3) if federal-question jurisdiction can be recognized without upsetting any "congressionally approved balance of federal and state judicial responsibilities.",261

This is the way the Court saves the jurisdictional holding in Smith. The Court acknowledges that Holmes was correct regarding the general rule that jurisdiction exists only if the plaintiff's authority to sue is grounded in federal law and takes the view that Justice Day's holding that jurisdiction was established could not rest on that general proposition for want of a federal statute permitting the shareholder action. ${ }^{262}$ Nevertheless, federal jurisdiction could still be secured, because the Grable tests were satisfied. The shareholder advanced a serious challenge to the constitutionality of a federal statute, the parties fiercely disputed the merits, the constitutional questions were best addressed originally in federal rather than state court, and there was no reason to think that federal jurisdiction threatened any discernible congressional expectation that attacks on the 1916 Act would be litigated in state court. ${ }^{263}$ So Holmes was right in general but wrong in particular. The Smith case was an exception to the general proposition that federalquestion jurisdiction turns on the plaintiff's federal authorization to take his or her complaint to court.

This rationalization of Smith has excited a reevaluation of the jurisdictional issue in this old case. Recent scholarship has done two things, neither of them threatening to the Court's modern position.

First, it has been demonstrated that the parties in Smith were justified in thinking that subject matter jurisdiction was secure. At the time,

\footnotetext{
260. Grable \& Sons Metal Prods., Inc. v. Darue Eng'g \& Mfg., 545 U.S. 308, 312-15 (2005).

261. Id. at 311-13.

262. The "sue and be sued" clause cannot be read to have authorized private suits to challenge the Act. See supra notes 162-64 and accompanying text.

263. See Grable, 545 U.S. at 314.
} 
jurisdiction was commonly sustained when plaintiffs raised federal questions in actions that were almost certainly conceived to be warranted by nonfederal law. The authority for private suits was often unstated. Many probably went forward under local law, more perhaps under uniform federal principles of equity and the general law applied in the federal courts prior to Erie. ${ }^{264}$ The Smith case itself may be understood, in hindsight, as a general-law action. ${ }^{265}$ This is not to suggest that the authority to sue in Smith was federal, after all. The "federal general common law" 266 disclaimed in Erie was federal in the sense that it was applied in the federal courts - not in the sense that it might have justified federal-question jurisdiction apart from diversity. ${ }^{267}$ The lesson from the old precedents is that the absence of a federal statute expressly sanctioning private suits was not generally thought to be telling, or even worth passing notice. ${ }^{268}$

The revelation that the jurisdictional holding in Smith conformed to conventional thinking in its own time obviously challenges the modern tendency to see Smith as an aberration. But it poses no serious threat to the Court's position that federal-question jurisdiction today should ordinarily turn on the foundation of the plaintiff's ability to sue. It appears that Smith had more company than was previously thought, so Smith is a harder precedent to reconcile even as an acceptable outlier. But that is no great difficulty. No one thinks Supreme Court precedents in this or any context are so continuous as the Justices make them out to

264. Michael G. Collins, "Economic Rights," Implied Constitutional Actions, and the Scope of Section 1983, 77 GEO. L.J. 1493, 1527 (1989) [hereinafter Economic Rights]; Ann Woolhandler \& Michael G. Collins, Federal Question Jurisdiction and Justice Holmes, 84 NOTRE DAME L. Rev. 2151, 2177-78 (2009). See also Kristin A. Collins, “A Considerable Surgical Operation”: Article III, Equity, and Judge-Made Law in the Federal Courts, 60 DukE L.J. 249 (2010) (demonstrating that in nineteenth-century cases federal courts employed equitable remedies of their own creation irrespective of the forms of relief available in the forum state's courts); John Harrison, Ex parte Young, 60 STAN. L. REV. 989, 1014 \& nn.100 \& 103 (2008) (contending that "anti-suit" actions for injunctions were probably understood this way). Michael Collins describes these suits as having been brought "directly" under the federal-question jurisdictional statute. But he contemplates that a litigant needed a separable authority to sue, which could be supplied by state law or general law. See Erie R.R. Co. v. Tompkins, 304 U.S. 64 (1938). Cf. Cohen v. Beneficial Indus. Loan Corp., 337 U.S. 541, 556 (1949) (describing the effects of Erie on shareholder suits). Holmes, of course, famously disdained the very idea of general law. Black \& White Taxicab Transfer Co. v. Brown \& Yellow Taxicab Transfer Co., 276 U.S. 518, 532-36 (1928) (Holmes, J., dissenting).

265. Collins, Economic Rights, supra note 264, at 1527 n.182.

266. Erie R.R. Co., 304 U.S. at 78 (emphasis added).

267. See William A. Fletcher, The General Common Law and Section 34 of the Judiciary Act of 1789: The Example of Marine Insurance, 97 HARV. L. REV. 1513, 1521-24 (1984) (explaining that general law was not understood to be part of the supreme federal law).

268. See Woolhandler \& Collins, supra note 264, at 2177-78. 
be.

The second thing recent scholarship has done is to recover a familiar and unremarkable characteristic of Holmes's thinking - namely, that Holmes himself regarded a litigant's entitlement to go to court to vindicate a substantive claim as inseparable from the legal claim the litigant went to court to vindicate. ${ }^{269}$ One may say that Holmes embraced the idea inherent in the common law that there could be no right without a remedy-meaning a judicial remedy. The common law was largely a body of individual rights and correlative duties. The only law to be enforced was one person's duty to respect another's rights, and the only institution available to enforce that law was a court. So there was no occasion to differentiate a plaintiff's argument about the lawfulness of a defendant's conduct from his or her entitlement to ask a court for help. A legal argument was intelligible only if it could be advanced by means of a private suit.

Now then, common law thinking may have been more formalistic. Authoritative commentaries drew the very distinction Holmes denied between primary rights and remedial rights, albeit they recognized that the two necessarily functioned together hand in glove. So when Holmes insisted that there was only one idea at work, he may have been articulating his own peculiar jurisprudence or, perhaps, signaling resistance to the disintegration of claims and judicial remedies he perceived to be under way in American law. ${ }^{270}$

This insight into Holmes's thinking would seem to undercut the modern Court's reliance on Holmes for the general proposition that federal-question jurisdiction turns on the source of the plaintiff's authority for bringing suit. If Holmes saw no difference between claims and the entitlement to seek a judicial remedy for claims, it is hard to cite him for the view that the authority to sue was a separate matter that had to be federal if jurisdiction was to be triggered. Yet academicians who come this far with Holmes tend to draw the conclusion that Holmes is a fair citation for the modern Court's ends. This is the way the story goes.

The two ideas recovered in recent scholarship (the routine recognition of federal jurisdiction when federal substantive claims were advanced and Holmes's rejection of any distinction between substantive

269. Id. at 2178-81; LARRY YACKLE, FEDERAL COURTS 215 n.177 (1st ed. 1999); Lumen N. Mulligan, You Can't Go Holmes Again, 107 Nw. U. L. ReV. 238, 244-46 (2012).

270. See Woolhandler \& Collins, supra note 264, at 2155-56; Mulligan, supra note 269, at 247 (describing Holmes as fighting a "rearguard action"). 
claims and the ability to take them to court) explain the difference between Day and Holmes in more or less the way the modern Court does. Justice Day, for his part, adhered to the prevailing view that the federal character of a plaintiff's properly pleaded claim established federal-question jurisdiction. Day, it is contended, did not pause to consider the source of the shareholder's authority to ask the courts to do something for him if his claim was meritorious - because (to Day) it did not matter. All that did matter for purposes of subject matter jurisdiction was that the argument itself was federal. Justice Holmes, so the story goes, thought it was nonsense to discuss a legal argument in the abstract, apart from the meaning it enjoyed as a means of obtaining judicial relief. So in practical effect Holmes introduced the plaintiff's vehicle for seeking a judicial remedy as an additional consideration-even as he denied that a litigation-authorizing vehicle was separable from the argument at all. ${ }^{271}$

It is possible to read Holmes's dissent to say that federal jurisdiction was wanting, because federal law supplied no "remedies" for shareholders in Smith's position. ${ }^{272}$ This is to say, Holmes thought the source of the authority to sue was critical to jurisdiction, and he complained that Day refused to look beyond the abstract claim that the bonds were unlawful. Yet there is another interpretation, indeed, another understanding of the Smith case as a whole, that is more plausible and more in keeping with the ostensible purpose of the Day and Holmes opinions to engage each other on the jurisdictional question. Recall Holmes's language specifically:

If the Missouri law authorizes or forbids the investment according to the determination of this Court upon a point under the Constitution or Acts of Congress, still that point is material only because the Missouri law saw fit to make it so. The whole foundation of the duty is Missouri law, which at its sole will incorporated the other law as it might incorporate a document. The other law or document depends for its relevance and effect not on its own force but upon the law that took it up, so I repeat once more the cause of action arises wholly from the law of the State. ... It may be enough that the law relied upon creates a part of the cause of action although not the whole, as held in [Osborn].... But the law must create at least a part of the cause of action by its own force, for it is the suit, not a question in the suit, that must arise under the law of the United States. The mere adoption by a State law of a United States law as a criterion or test, when the law of the United

271. See Woolhandler \& Collins, supra note 264, at 2153; Mulligan, supra note 269, at 244-49.

272. See Woolhandler \& Collins, supra note 264, at 2184. 
States has no force proprio vigore, does not cause a case under the

State law to be also a case under the law of the United States ....

The starting point for this alternative account is the notorious ambiguity of the "cause of action" phrase. ${ }^{274}$ Today, that label is attached to the vehicle on which a plaintiff rests his or her entitlement to seek judicial relief. The Court reads Justice Holmes to have given the "cause of action" formulation the same meaning. But scholarship has shown the Court's understanding to be wrong. Holmes did not recognize a litigant's authority to sue as a question separate from his or her legal argument. According to this alternative account of Smith, neither did Justice Day. He, too, declared that "the jurisdiction of the District Court depend[ed] on whether the cause of action set forth [arose] under the Constitution ....,"275

We must open our minds to the possibility that Day, as well as Holmes, treated the substantive legal claim and the shareholder's ability to take it to court as one and the same. The latter was a necessary feature of the former, requiring no separate investigation. So it is not that Day slid past the source of the shareholder's authority to sue the Trust Company and that Holmes called Day back to that issue. When Day and Holmes used the "cause of action" phrase, neither meant to introduce the plaintiff's authority to sue as an independent matter. Both used "cause of action" to mean the legal argument - the claim. The law that had to be federal was the law that created a plaintiff's legal argument, the law that governed the parties' primary behavior, the law the plaintiff insisted the defendant was violating, the law that allegedly made the defendant's behavior a legal wrong, the law that a federal court would be asked to use as a rule of decision.

By this account, the difference between Day and Holmes was over whether the shareholder's claim was genuinely federal. Day thought so, because the district court would have to determine a federal constitutional question to resolve it. A state claim incorporating a federal element was federal within the meaning of the jurisdictional statute. ${ }^{276}$ Holmes thought not. He agreed that the action arose under the law that

273. Smith v. K.C. Title \& Trust Co., 255 U.S. 180, 214-15 (1921) (Holmes, J., dissenting).

274. See LARry YACKLE, Federal CourTs 240-45 (3d ed. 2009) (breaking out the ideas behind the "cause of action" label); but see Lumen N. Mulligan, A Unified Theory of 28 U.S.C. $\S$ 1331 Jurisdiction, 61 VAND. L. REV. 1667, 1674 (2008) (offering a different account).

275. Smith, 255 U.S. at 199 (emphasis added).

276. Cf. Lumen N. Mulligan, Jurisdiction by Cross-Reference, 88 WASH. U. L. Rev. 1177, 1209-10 (2011) (describing this arrangement as "mandatory cross-referencing" state to federal). 
supported the claim - the substantive law the district court would use to resolve the dispute. But, in his mind, that was state law alone. The only duty the shareholder charged the Trust Company with violating was a duty established by state law. The state-law nature of the company's duty did not change merely because state law incorporated federal law as its content. Still, the alleged breach of a state duty made out only a state law claim. When Holmes said it was the suit, not a question in the suit, that must be federal, he did not mean the vehicle for seeking judicial relief rather than the claim the shareholder employed the vehicle to advance. He meant the claim rather than an issue embedded in the claim. ${ }^{277}$

This explanation does conflict with the modern Court's understanding inasmuch as it leaves the source of the plaintiff's authority to sue entirely out of the picture. Moreover, it may be off-putting in that it makes Holmes (of all people) sound formalistic. Everyone understood that Missouri law provided only the outer shell of the claim in Smith and that the real issue dividing the parties was the constitutionality of the tax exemptions for farm bonds. Yet Holmes himself often acknowledged the need for comparatively rigid rules that supply predictability when needed. ${ }^{278}$ Moreover, the modern Court's (mis)understanding of Holmes in this context is typically justified, in part, on the ground that it provides a comparatively fixed, administrable means of ascertaining jurisdiction at the courthouse door. ${ }^{279}$

The more serious objection is that this view of Holmes makes him blind to the practical implications of his position. If the Court had held in Smith that the district court lacked jurisdiction, the only consequence would have been delay. Bullitt would have backed up, filed essentially the same suit in state court, and ultimately returned to the Supreme Court on direct review of a state court judgment. ${ }^{280}$ In the meantime, a bad situation would only have become worse. The value of outstanding farm bonds would have plummeted even more, and the market for more bond

277. Holmes may have distinguished a suit from a question in a suit merely to acknowledge that some claims implicate both federal and state issues; he cited Osborn, where John Marshall had made that (obvious) point. If, however, that is all Holmes meant, he still was focused on the shareholder's legal argument against the Trust rather than on the source of the shareholder's ability to seek judicial relief.

278. See Gerald J. Postema, Legal Philosophy in the Twentieth Century: The COMMON LAW WORLD 67, 75 (2011).

279. E.g., Grable \& Sons Metal Prods., Inc. v. Darue Eng'g \& Mfg., 545 U.S. 308, 320-21 (Thomas, J., concurring).

280. E.g., Louisville \& Nashville R.R. Co. v. Layton, 243 U.S. 617 (1917). 
sales would have disintegrated. The country was already suffering dislocations brought on by the war and could scarcely afford further unsettlement in the economy. The Court had already postponed action on the case for months, apparently to hear Holmes out. By the winter of 1921, it was time to clear the air.

None of this is to broach the question whether jurisdiction under $\S$ 1331 should generally turn on whether Congress has authorized private litigation. Today, of course, judicial remedies for legal wrongs are not indispensable in every instance. There are lots of alternative mechanisms by which to implement federal law-for example, agency enforcement. Accordingly, the authorization (or not) of private litigation presents an independent policy decision in every context. The Court, for its part, now wants Congress actually to address and decide whether to include private lawsuits in the mix, if not as the primary means of enforcement then as supplemental to public mechanisms. Congress may exclude private actions lest they interfere with administrative schemes and the exercise of discretion by responsible officials. Then, too, Congress may withhold authority for private litigation as part of the compromise necessary to agreement on substantive provisions. Bluntly stated, a minority may acquiesce in a program in chief but use its political muscle to attack at the flank by denying the new law this familiar, and typically effective, means of enforcement. There is a rich literature on these policy questions and the ideological influences at work. $^{281}$

This biography of the old Smith case offers no insight into the wisdom of the Court's current agenda. Suffice it to say that the argument for making congressional authorization of suits the key to federalquestion jurisdiction is most powerful with respect to the enforcement of federal law for which Congress itself is responsible. The Court no longer finds "causes of action" implicit in federal statutes and instead demands explicit provisions $;{ }^{282}$ this on the theory that Congress should decide how its own legislative programs should be implemented. Making jurisdiction turn on the same fulcrum is at least consistent. A similar argument cannot so easily explain the Court's treatment of private suits advancing federal constitutional claims of right. ${ }^{283}$ Suits attacking the

281. See, e.g., Sunstein, supra note 156, at 416.

282. See Alexander v. Sandoval, 532 U.S. 275, 286-89 (2001).

283. See, e.g., Schweiker v. Chilicky, 487 U.S. 412 (1989) (dealing with actions to enforce constitutional rights); id. at $429 \mathrm{n} .3$ (acknowledging the possibility that Congress might foreclose private actions). 
constitutionality of congressional schemes are farther afield. It would be dangerous to let Congress mind the door alone when its own law-making is challenged. Then again, the Court has not done that and, indeed, has rationalized an exception to its general rule in cases like Smith-for the good reasons the Grable criteria bring to light.

What should be clear, however, is that the idea for which Smith is now known - that is, the idea that federal-question jurisdiction rarely exists in the absence of a federal statute authorizing private suits-is ahistorical. Recent scholarship demonstrates that when Smith was decided the Supreme Court commonly found federal-question jurisdiction when the plaintiff's remedial right was nonfederal. But the truth lies deeper. The whole notion that a private litigant's entitlement to pursue judicial relief constitutes a separate, threshold issue distinct from a legal claim is an artifact of the administrative state. This is not an idea that can be retrofitted. It cannot, or at least should not, be imposed on the world as it was before the emergence of the modern menu of enforcement mechanisms from which Congress makes choices. When Smith was decided, the working assumption was that private lawsuits were the only game in town.

\section{EPILOGUE}

The subsequent history of the federal banks approved in Smith was peaks and valleys. Many more Joint Stock Banks were chartered (about 87 over the life of the program), most were profitable during World War I, but all suffered in the post-war economic decline. ${ }^{284}$ In 1923, Congress limited the size of Joint Stock Bank loans to \$50,000 and restricted their purpose to agricultural projects. When the crash came in 1929, the government provided emergency assistance to Land Banks, but not to Joint Stock Banks. The Reconstruction Finance Corporation loaned some funds to Joint Stock Banks, but not enough money to save them. In short order, they began to fail. The Emergency Farm Mortgage Act of 1933 created a number of new federal institutions to supply rural credit, but provided for the liquidation of all the Joint Stock Banks still standing. ${ }^{285}$

Federal Land Banks survived the post-war period and then made much-needed loans during the Great Depression. In 1933, President

\footnotetext{
284. Murray R. Benedict, Farm Policies of THE United States, 1790-1950, 147 (1953).

285. Bennett, supra note 64, at 861.
} 
Roosevelt abolished the Farm Loan Board and transferred its supervisory responsibility for Land Banks to a new Farm Credit Administration. ${ }^{286}$ Over succeeding decades, numerous reorganization plans perpetuated Land Banks along with other rural credit entities. ${ }^{287}$ Land Banks were still in existence on their fiftieth anniversary in $1967,{ }^{288}$ but public funding for loans to farmers was diminishing fast. ${ }^{289}$ The Agricultural Credit Act of 1987 collapsed the Land Banks into Farm Credit Banks. ${ }^{290}$

Shareholder suits continued to serve as instruments by which corporations unable to sue straightforwardly to advance their economic interests could challenge competing public institutions by proxy. In his famous concurrence in the Ashwander case, Justice Brandeis worried aloud that individuals suing as shareholders could challenge federal regulatory programs even when corporations themselves failed to do so (at least formally). Brandeis recognized the threat to social welfare policy and so contended that the policing of corporate boards should generally be left to public officials. ${ }^{291}$ Yet the full Court was content with the shareholder model and, in Ashwander itself, explicitly relaxed the standards for derivative actions that had been in place when Smith was decided. ${ }^{292}$ Shareholder suits figured in some of the most famous attacks on federal legislation before and during the New Deal. The Carter Coal case was a shareholder suit, ${ }^{293}$ as was the Social Security case, Helvering v. Davis. ${ }^{294}$

The principal players in Smith passed on to other notable pursuits. Charles Evans Hughes became Secretary of State in the Harding Administration. Then Herbert Hoover named him Chief Justice in 1930.

286. Franklin Delano Roosevelt, Message and Executive Order Consolidating Federal Farm Credit Agencies, in 2 Public PAPERS AND AdDresses of Franklin D. RoOSEVElt, 1938, at 84.

287. W. GIFFORD HoAG, THE FARM CREDIT SySTEM: A HiSTORY OF FinANCIAL SELF-HELP 1-2 (1976).

288. Tootell, supra note 24, at 557-61.

289. Warren F. Lee \& George D. Irwin, Restructuring the Farm Credit System: A Progress Report, 56 AGRIC. Fin. ReV. 1, 7 (1996).

290. Id. at 9; see also Farrell E. Jensen, The Farm Credit System as a Government-Sponsored Enterprise, 22 REV. AGRIC. ECON. 226, 328 (2000) (listing the putative purposes of the change); Kenneth L. Peoples, Anatomy of an American Agricultural Credit Crisis: Farm DebT in THE 1980S, 75-89 (1992) (offering more background).

291. Ashwander v. Tenn. Valley Auth., 297 U.S. 288, 343 (1936) (Brandeis, J., concurring).

292. Id. at 318-19 (majority opinion) (holding that it was unnecessary to show that company directors' actions were ultra vires and that the necessary "illegality" could be found "in the lack of lawful authority on the part of those with whom the corporation [was] attempting to deal"-namely, the allegedly unconstitutional conduct of the TVA).

293. Carter v. Carter Coal Co., 298 U.S. 238 (1936).

294. 301 U.S. 619 (1937). 
It is tempting to say that Hughes's experience in Smith influenced his attitude toward congressional power on his return to the Court. But his briefs on behalf of Federal Land Banks contended, and needed to contend, only that Congress could create public entities to finance agriculture carried on privately - not that Congress could regulate the industry in fine detail, far less actually "conduct agricultural activities."295 So Hughes could write for the Court without embarrassment in the Sick Chicken Case, Schechter Poultry, one of the infamous Black Monday decisions that precipitated the confrontation with FDR over New Deal legislation. ${ }^{296}$

Then again, Hughes wrote the majority opinion in Ashwander, delivered less than a year later. ${ }^{297}$ There, too, he was cautious, declining to face the question whether the very existence of the Tennessee Valley Authority was constitutional. But he did address and sustain the TVA's construction and operation of the great Wilson Dam and the sale of electric power throughout the region. The plaintiffs contended that if Congress could create a public institution with those authorities, then Congress must be able to engage in other kinds of business (steel manufacturing to shoe making). ${ }^{298}$ To that, Hughes responded that he would decide only the case at hand. ${ }^{299}$ It was Justice McReynolds, in dissent, who insisted that Congress had no power to authorize the TVA "or any other federal agency" to engage in such far-reaching commercial activities. $^{300}$ Of course, Hughes also wrote for the Court in Jones \& Laughlin Steel, which by all accounts (apart from his own) largely repudiated the analysis in Schechter and marked the Court's essential capitulation to Roosevelt and the New Deal Congress. ${ }^{301}$ The rest, as they say, is history.

George Wickersham assumed a variety of roles as a senior

295. Supplemental Brief for Appellee, Federal Land Bank of Wichita, Kansas, at 26, Smith v. K.C. Title \& Trust Co., 255 U.S. 180 (1921) (No. 199) (brief on reargument) (disclaiming such a power).

296. A.L.A. Schechter Poultry Corp. v. United States, 295 U.S. 495 (1935).

297. Ashwander v. Tenn. Valley Auth., 297 U.S. 288 (1936).

298. Id. at 339-40.

299. Id.

300. Id. at 371-72 (McReynolds, J., dissenting).

301. NLRB v. Jones \& Laughlin Steel Corp., 301 U.S. 1 (1937). See Thurmond ARnold, The FolKLORE OF CAPITALISM 339 (1937). But cf. F.D.G. Ribble, The Constitutional Doctrines of Chief Justice Hughes, 41 CoLUM. L. REv. 1189, 1199 (1941) (describing Hughes's apparent shift as "in no sense an about face" but rather "an adjustment of a scale"). Hughes himself denied any cause-andeffect relationship between the court-packing plan and the course of the Court's decisions. AUTOBIOGRAPHICAL NOTES, supra note 215, at 311-13. 
statesman. He was for a time President of the Council on Foreign Relations. He is remembered today as chair of the National Commission on Law Observance and Enforcement, the first systematic investigation of law enforcement in the United States. The Wickersham Commission's multi-volume report described widespread police misconduct, particularly harsh interrogation methods, as well as political corruption. The Commission documented the many failings of Prohibition, but declined to recommend its repeal (suffering no end of ridicule for its lack of resolve). ${ }^{302}$

William McAdoo, the "father" of the Farm Loan Act and its most vigorous proponent, entered politics in his own right. His name was placed in nomination for the presidency in 1920, but his heart wasn't in it. ${ }^{303}$ Four years later, he battled Al Smith for the nomination at the marathon convention that ultimately settled on John W. Davis. ${ }^{304}$ In 1933, McAdoo was elected to the Senate from California.

Judge Van Valkenburgh handled a number of other important cases, including Missouri v. Holland. ${ }^{305}$ During World War I, he presided at the trials of Communist Party members. Later, President Coolidge appointed Van Valkenburgh to the circuit bench. Justice Day, always a frail man, retired from the Court a year after the Smith decision and died the year after that.

William Marshall Bullitt continued his career as a corporate litigator. He became principal counsel to the Whiskey Trust and made one of the arguments in National Prohibition Cases. ${ }^{306}$ His prized store of mathematical materials can now be found in the University of Louisville Library. Near the end of his career, Bullitt was actively engaged in the Alger Hiss affair. He composed a survey of the congressional hearings, which painted an unflattering picture of Hiss. ${ }^{307}$ The year before his death, Bullitt was the victim of what was then the largest theft of cash in American history. ${ }^{308}$ At the last, the former champion of private banks

\footnotetext{
302. Prohibition: Wickershambles, TIME, Feb. 2, 1931, at 8.

303. McAdoo Plans Active Aid in Cox Campaign, N.Y. TriBune, July 7, 1920, at 3 (reporting that McAdoo sent a telegram insisting that he was not a candidate).

304. See Lee N. Allen, The McAdoo Campaign for the Presidential Nomination in 1924, 29 J.S. HIST. 211 (1963).

305. U.S. v. Samples, 258 F. 479 (W.D. Mo. 1919), aff'd sub nom Missouri v. Holland, 252 U.S. 416 (1920).

306. Evans v. Gore, 253 U.S. 250 (1920); DAVIS, supra note 10, at 89-91.

307. William Marshall Bullitt, A Factual Review of the Whittaker ChambersAlger Hiss Controversy (1948). See DAVIS, supra note 10, at 191-207.

308. DAVIS, supra note 10, at 219-31.
} 
was unwilling to trust his own money to their keeping. 